\title{
Synthesis, Property Characterization, and Photocatalytic Activity of Novel Visible Light-Responsive Photocatalyst $\mathrm{Fe}_{2} \mathrm{BiSbO}_{7}$
}

\author{
Jingfei Luan and Zhitian Hu \\ State Key Laboratory of Pollution Control and Resource Reuse, School of the Environment, Nanjing University, Nanjing 210093, China \\ Correspondence should be addressed to Jingfei Luan, jfluan@nju.edu.cn \\ Received 15 July 2011; Accepted 2 September 2011 \\ Academic Editor: Shifu Chen \\ Copyright () 2012 J. Luan and Z. Hu. This is an open access article distributed under the Creative Commons Attribution License, \\ which permits unrestricted use, distribution, and reproduction in any medium, provided the original work is properly cited. \\ $\mathrm{Fe}_{2} \mathrm{BiSbO}_{7}$ was synthesized by a solid-state reaction method for the first time. The structural and photocatalytic properties of \\ $\mathrm{Fe}_{2} \mathrm{BiSbO}_{7}$ have been characterized. The results showed that $\mathrm{Fe}_{2} \mathrm{BiSbO}_{7}$ was crystallized with the pyrochlore-type structure, \\ cubic crystal system, and space group $\mathrm{Fd} 3 \mathrm{~m}$. The lattice parameter for $\mathrm{Fe}_{2} \mathrm{BiSbO}_{7}$ was $a=10.410297 \AA$. The photocatalytic \\ degradation of methylene blue $(\mathrm{MB})$ was realized under visible light irradiation with $\mathrm{Fe}_{2} \mathrm{BiSbO}_{7}$ as catalyst. $\mathrm{Fe}_{2} \mathrm{BiSbO}_{7}$ owned \\ higher catalytic activity compared with $\mathrm{Bi}_{2} \mathrm{InTaO}_{7}$ or pure $\mathrm{TiO}_{2}$ or $\mathrm{N}$-doped $\mathrm{TiO}_{2}$ for photocatalytic degradation of $\mathrm{MB}$. The \\ photocatalytic degradation of $\mathrm{MB}$ with $\mathrm{Fe}_{2} \mathrm{BiSbO}_{7}, \mathrm{Bi}_{2} \mathrm{InTaO}_{7}$, or $\mathrm{N}$-doped $\mathrm{TiO}_{2}$ followed the first-order reaction kinetics, and

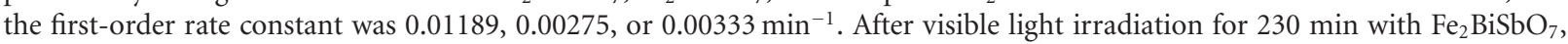 \\ complete removal and mineralization of $\mathrm{MB}$ was observed. The reduction of the total organic carbon, the formation of inorganic \\ products, $\mathrm{SO}_{4}{ }^{2-}$ and $\mathrm{NO}_{3}{ }^{-}$, and the evolution of $\mathrm{CO}_{2}$ revealed the continuous mineralization of MB during the photocatalytic \\ process. The photocatalytic degradation pathway of $\mathrm{MB}$ was obtained. $\mathrm{Fe}_{2} \mathrm{BiSbO}_{7} /$ (visible light) photocatalysis system was found \\ to be suitable for textile industry wastewater treatment.
}

\section{Introduction}

Dye effluents from textile industries and photographic industries are becoming a serious environmental problem because of their toxicity, unacceptable color, high chemical oxygen demand content, and nonbiological degradation [1]. Many conventional methods have been proposed to treat industrial effluents, but each method has its shortcomings [1-7]. In recent years, the photocatalytic degradation processes have been widely applied as techniques of destruction of organic pollutants in wastewater and effluents, especially for degrading dyes [1, 7-21]. However, among various dyes, methylene blue (MB) dye was difficult to be degraded and was often utilized as a model dye contaminant to estimate the activity of a photocatalyst under both ultraviolet light irradiation $[18,19,22]$ and visible light irradiation $[20,21,23,24]$. There were many reports about the photodegradation of MB. Unfortunately, most of these reports were carried out under UV light irradiation. Up to now, there were only few reports of MB dye degradation under visible light irradiation such as the research by Asahi et al. with a reduced $\mathrm{TiO}_{x}\left(\mathrm{TiO}_{2-x} \mathrm{~N}_{x}\right)$ as catalyst and the research by Tang et al. and Cui et al. with Pt- $\mathrm{TiO}_{2}$ as photocatalyst $[21,24]$. Zhang [25] utilized Ndoped $\mathrm{TiO}_{2}$ as catalyst to degrade $\mathrm{MB}$ under visible light irradiation and found that the removal ratio of $\mathrm{MB}$ was only $35 \%$ after $180 \mathrm{~min}$. It is known that ultraviolet light only occupies $4 \%$ of the solar energy. For this reason, many endeavors should be taken up to develop new visible lightresponsive photocatalysts which are capable of utilizing more visible light, which accounts for about $43 \%$ of the solar energy. Therefore, it is urgent to develop novel visible lightresponsive photocatalysts.

With the development of investigation of photocatalysis process, investigators also paid much attention to researching and developing novel photocatalysts [26-30]. Currently, $\mathrm{TiO}_{2}$ was the most common photocatalyst, however, $\mathrm{TiO}_{2}$ could not be utilized in the visible light region and could only degrade $\mathrm{RhB}$ under ultraviolet light irradiation which was a restrained factor for photocatalysis technology with $\mathrm{TiO}_{2}$ as catalyst. Therefore, some efficient catalysts which could generate electron-hole pairs under visible light irradiation should be developed. Fortunately, $\mathrm{A}_{2} \mathrm{~B}_{2} \mathrm{O}_{7}$ compounds were 
often considered to own photocatalytic properties under visible light irradiation. In our previous work [31], we have found that $\mathrm{Bi}_{2} \mathrm{InTaO}_{7}$ was crystallized with the pyrochloretype structure and acted as a photocatalyst under visible light irradiation and seemed to have potential for improvement of photocatalytic activity upon modification of its structure. According to the above analysis, we could assume that substitution of $\mathrm{Ta}^{5+}$ by $\mathrm{Sb}^{5+}$, substitution of $\mathrm{Bi}^{3+}$ by $\mathrm{Fe}^{3+}$, and substitution of $\mathrm{In}^{3+}$ by $\mathrm{Bi}^{3+}$ in $\mathrm{Bi}_{2} \mathrm{InTaO}_{7}$ might increase carriers concentration. As a result, a change and improvement of the electrical transportation and photophysical properties could be found in the novel $\mathrm{Fe}_{2} \mathrm{BiSbO}_{7}$ compound which might own advanced photocatalytic properties.

$\mathrm{Fe}_{2} \mathrm{BiSbO}_{7}$ has never been produced before and the data about its structural and photophysical properties such as space group and lattice constants have not been found previously. In addition, the photocatalytic properties of $\mathrm{Fe}_{2} \mathrm{BiSbO}_{7}$ have not been studied by other investigators. The molecular composition of $\mathrm{Fe}_{2} \mathrm{BiSbO}_{7}$ was very similar with other $\mathrm{A}_{2} \mathrm{~B}_{2} \mathrm{O}_{7}$ compounds. Thus the resemblance suggested that $\mathrm{Fe}_{2} \mathrm{BiSbO}_{7}$ might possess photocatalytic properties under visible light irradiation, which was similar with those other members in $\mathrm{A}_{2} \mathrm{~B}_{2} \mathrm{O}_{7}$ family. $\mathrm{Fe}_{2} \mathrm{BiSbO}_{7}$ also seemed to own potential for improvement of photocatalytic activity upon modification of its structure because it had been proved that a slight modification of a semiconductor structure will result in a remarkable change within photocatalytic properties [21]. In this paper, $\mathrm{Fe}_{2} \mathrm{BiSbO}_{7}$ was prepared for the first time by the solid-state reaction method and the structure and photocatalytic properties of $\mathrm{Fe}_{2} \mathrm{BiSbO}_{7}$ were investigated in detail. The photocatalytic degradation of $\mathrm{MB}$ under visible light irradiation was also performed to evaluate the photocatalytic activity of $\mathrm{Fe}_{2} \mathrm{BiSbO}_{7}$. A comparison among the photocatalytic properties of $\mathrm{Fe}_{2} \mathrm{BiSbO}_{7}, \mathrm{Bi}_{2} \mathrm{InTaO}_{7}$, and $\mathrm{N}$-doped $\mathrm{TiO}_{2}$ was achieved in order to elucidate the relationship between the structure and photocatalytic activity of $\mathrm{Fe}_{2} \mathrm{BiSbO}_{7}$.

\section{Experimental}

2.1. Synthesis of $\mathrm{Fe}_{2} \mathrm{BiSbO}_{7}$ and $\mathrm{N}$-Doped $\mathrm{TiO}_{2} \cdot \mathrm{Fe}_{2} \mathrm{BiSbO}_{7}$ powder was first synthesized by the solid-state reaction method. $\mathrm{Fe}_{2} \mathrm{O}_{3}, \mathrm{Bi}_{2} \mathrm{O}_{3}$, and $\mathrm{Sb}_{2} \mathrm{O}_{5}$ with the purity of $99.99 \%$ were utilized as raw materials which were purchased from Sinopharm Group Chemical Reagent Co. (Shanghai, China) and used without further purification. All powders were dried at $200^{\circ} \mathrm{C}$ for $4 \mathrm{~h}$ before synthesis. In order to synthesize $\mathrm{Fe}_{2} \mathrm{BiSbO}_{7}$, the precursors were stoichiometrically mixed in a quartz mortar, subsequently pressed into small columns, and put into an alumina crucible (Shenyang Crucible Co., Ltd., China). Finally, calcination was carried out at $1020^{\circ} \mathrm{C}$ for $25 \mathrm{~h}$ in an electric furnace (KSL 1700X, Hefei Kejing Materials Technology Co., Ltd., China). Similarly, $\mathrm{Bi}_{2} \mathrm{InTaO}_{7}$ was synthesized by calcination at $1050^{\circ} \mathrm{C}$ for $46 \mathrm{~h}$. After sintering and grounding within a quartz mortar, ultrafine $\mathrm{Fe}_{2} \mathrm{BiSbO}_{7}$ powder was fabricated. Nitrogen-doped titania (N-doped $\mathrm{TiO}_{2}$ ) catalyst with tetrabutyl titanate as a titanium precursor was prepared via the sol-gel method at room temperature. The procedure was as follows: $17 \mathrm{~mL}$ tetrabutyl titanate and $40 \mathrm{~mL}$ absolute ethyl alcohol were mixed as solution a, subsequently solution a was added dropwise under vigorous stirring into the solution $b$ that contained $40 \mathrm{~mL}$ absolute ethyl alcohol, $10 \mathrm{~mL}$ glacial acetic acid, and $5 \mathrm{~mL}$ double distilled water to form transparent colloidal suspension c. Subsequently aqua ammonia with N/Ti proportion of $8 \mathrm{~mol} \%$ was added into the resulting transparent colloidal suspension under vigorous stirring condition and kept stirring for $1 \mathrm{~h}$. Finally, the xerogel was formed after being aged for 2 days. The xerogel was grounded into powder which was calcined at $500^{\circ} \mathrm{C}$ for $2 \mathrm{~h}$. Finally, above powder was grounded in agate mortar and screened by shaker to obtain N-doped $\mathrm{TiO}_{2}$ powders.

2.2. Characterization of $\mathrm{Fe}_{2} \mathrm{BiSbO}_{7}$. The crystalline phase of $\mathrm{Fe}_{2} \mathrm{BiSbO}_{7}$ was analyzed by X-ray diffractometer (D/MAX$\mathrm{RB}$, Rigaku Corporation, Japan) with $\mathrm{Cu} K \alpha$ radiation $(\lambda=$ 1.54056). The patterns were collected at $295 \mathrm{~K}$ with a stepscan procedure in the range of $2 \theta=10-95^{\circ}$. The step interval was $0.02^{\circ}$ and the time per step was $1 \mathrm{~s}$. The accelerating voltage and applied current were $40 \mathrm{kV}$ and $40 \mathrm{~mA}$, respectively. The chemical composition of the compound was determined by scanning electron microscope-X-ray energy dispersion spectrum (SEM-EDS, LEO 1530VP, LEO Corporation, Germany), X-ray fluorescence spectrometer (XFS, ARL-9800, ARL Corporation, Switzerland), and X-ray photoelectron spectroscopy (XPS, ESCALABMK-2, VG Scientific Ltd., UK). The particle morphology of $\mathrm{Fe}_{2} \mathrm{BiSbO}_{7}$ was observed by transmission electron microscope (Tecnal F20 $\mathrm{S}$-Twin, FEI Corporation, USA). The $\mathrm{Fe}^{3+}$ content, $\mathrm{Bi}^{3+}$ content, $\mathrm{Sb}^{5+}$ content, and $\mathrm{O}^{2-}$ content of $\mathrm{Fe}_{2} \mathrm{BiSbO}_{7}$ and the valence state of elements were also analyzed by X-ray photoelectron spectroscopy (XPS). The chemical composition within the depth profile of $\mathrm{Fe}_{2} \mathrm{BiSbO}_{7}$ was examined by the argon ion denudation method when X-ray photoelectron spectroscopy was used. UV-visible diffuse reflectance spectrum of $\mathrm{Fe}_{2} \mathrm{BiSbO}_{7}$ was measured with a Shimadzu UV2550 UV-Visible spectrometer, and $\mathrm{BaSO}_{4}$ was used as the reference material. The surface areas of $\mathrm{Fe}_{2} \mathrm{BiSbO}_{7}$ and $\mathrm{N}$ doped $\mathrm{TiO}_{2}$ were determined by the Brunauer-EmmettTeller (BET) method (MS-21, Quantachrome Instruments Corporation, USA) with $\mathrm{N}_{2}$ adsorption at liquid nitrogen temperature. The particle sizes of the photocatalysts were measured by Malvern's mastersize-2000 particle size analyzer (Malvern Instruments Ltd., UK).

2.3. Photocatalytic Activity Tests. The photocatalytic activity of $\mathrm{Fe}_{2} \mathrm{BiSbO}_{7}$ was evaluated with methylene blue $\left(\mathrm{C}_{16} \mathrm{H}_{18} \mathrm{ClN}_{3} \mathrm{~S}\right)$ (Tianjin Bodi Chemical Co., Ltd., China) as a model material. The photoreaction was carried out in a photochemical reaction apparatus (Nanjing Xujiang Machine Plant, China). The internal structure of the reaction apparatus is as follows: the lamp is put into a quartz hydrazine which is a hollow structure and located in the middle of the reactor. The recycling water through the reactor maintains a near constant reaction temperature $\left(20^{\circ} \mathrm{C}\right)$ and the solution was continuously stirred and aerated. Twelve holes 
which are used to put quartz tubes evenly distribute around the lamp and the distance between the lamp and each hole is equal. Under the condition of magnetic stirring, the photocatalyst within the MB solution is in the state of suspension. In this paper, the photocatalytic degradation of the $\mathrm{MB}$ solution was performed with $0.3 \mathrm{~g} \mathrm{Fe}_{2} \mathrm{BiSbO}_{7}$ in $300 \mathrm{~mL}$ $0.025 \mathrm{mM} \mathrm{MB}$ aqueous solution in quartz tubes with $500 \mathrm{~W}$ Xenon lamp (400 $\mathrm{nm}<\lambda<800 \mathrm{~nm}$ ) as visible-light source. Prior to visible light irradiation, the suspensions which contained the catalyst and MB dye were magnetically stirred in the dark for 45 min to ensure establishment of an adsorption/desorption equilibrium among $\mathrm{Fe}_{2} \mathrm{BiSbO}_{7}$, the $\mathrm{MB}$ dye, and atmospheric oxygen. During visible light illumination, the suspension was stirred at $500 \mathrm{rpm}$ and the initial $\mathrm{pH}$ value of the $\mathrm{MB}$ solution was 7.0 without $\mathrm{pH}$ adjustment in the reaction process. The above experiments were performed under oxygen-saturation conditions $\left(\left[\mathrm{O}_{2}\right]_{\text {sat }}=1.02 \times\right.$ $\left.10^{-3} \mathrm{M}\right)$. One of the quartz tubes was taken out from the photochemical reaction apparatus at various time intervals. The suspension was filtered through $0.22 \mu \mathrm{m}$ membrane filters. The filtrate was subsequently analyzed by a Shimadzu UV-2450 UV-Visible spectrometer with the detecting wavelength at $665 \mathrm{~nm}$. The experimental error was found to be within $\pm 2.2 \%$.

The incident photon flux $I_{o}$ measured by a radiometer (Model FZ-A, Photoelectric Instrument Factory Beijing Normal University, China) was determined to be $4.76 \times 10^{-6}$ Einstein $\mathrm{L}^{-1} \mathrm{~s}^{-1}$ under visible light irradiation (wavelength range of $400-700 \mathrm{~nm}$ ). The incident photon flux on the photoreactor was varied by adjusting the distance between the photoreactor and the $\mathrm{Xe}$ arc lamp. The $\mathrm{pH}$ value adjustment was not carried out, and the initial $\mathrm{pH}$ value was 7.0. The inorganic products which were obtained from $\mathrm{MB}$ degradation were analyzed by ion chromatograph (DX-300, Dionex Corporation, USA). The identification of MB and the degradation intermediate products of $\mathrm{MB}$ were performed by gas chromatograph-mass spectrometer (GC-MS, HP 6890 Series Gas Chromatograph, AT column, $20.3 \mathrm{~m} \times 0.32 \mathrm{~mm}$, ID of $0.25 \mu \mathrm{m}$ ) which operated at $320^{\circ} \mathrm{C}$ and was connected to HP 5973 mass selective detector and a flame ionization detector with $\mathrm{H}_{2}$ as the carried gas. The intermediate products of $\mathrm{MB}$ were also measured by liquid chromatographmass spectrometer (LC-MS, Thermo Quest LCQ Duo, USA, Beta Basic-C 18 HPLC column: $150 \times 2.1 \mathrm{~mm}$, ID of $5 \mu \mathrm{m}$, Finnigan, Thermo, USA). Here, $20 \mu \mathrm{L}$ of postphotocatalysis solution was injected automatically into the LC-MS system. The fluent contained $60 \%$ methanol and $40 \%$ water, and the flow rate was $0.2 \mathrm{~mL} \mathrm{~min}^{-1}$. MS conditions included an electrospray ionization interface, a capillary temperature of $27^{\circ} \mathrm{C}$ with a voltage of $19.00 \mathrm{~V}$, a spray voltage of $5000 \mathrm{~V}$, and a constant sheath gas flow rate. The spectrum was acquired in the negative ion scan mode and the $m z^{-1}$ range swept from 50 to 600 . Evolution of $\mathrm{CO}_{2}$ was analyzed with an intersmat IGC120-MB gas chromatograph equipped with a porapack $\mathrm{Q}$ column (3 $\mathrm{m}$ in length and an inner diameter of $0.25 \mathrm{in}$.), which was connected to a catharometer detector. The total organic carbon (TOC) concentration was determined with a TOC analyzer (TOC-5000, Shimadzu Corporation, Japan).
The photonic efficiency was calculated according to the following equation $[32,33]$ :

$$
\varphi=\frac{R}{I_{o}},
$$

where $\varphi$ is the photonic efficiency (\%), $R$ is the rate of MB degradation $\left(\mathrm{Mol} \mathrm{L}^{-1} \mathrm{~s}^{-1}\right)$, and $I_{o}$ is the incident photon flux (Einstein $\mathrm{L}^{-1} \mathrm{~s}^{-1}$ ).

\section{Results and Discussion}

3.1. Crystal Structure of $\mathrm{Fe}_{2} \mathrm{BiSbO}_{7}$. Figure 1 presents TEM image and the selected area electron diffraction pattern of $\mathrm{Fe}_{2} \mathrm{BiSbO}_{7}$. The TEM image of $\mathrm{Fe}_{2} \mathrm{BiSbO}_{7}$ showed that the morphology of the $\mathrm{Fe}_{2} \mathrm{BiSbO}_{7}$ particle was very similar and regular. It could be seen that the $\mathrm{Fe}_{2} \mathrm{BiSbO}_{7}$ particles crystallized well and the mean particle diameter of $\mathrm{Fe}_{2} \mathrm{BiSbO}_{7}$ was about $150 \mathrm{~nm}$. SEM-EDS spectrum of $\mathrm{Fe}_{2} \mathrm{BiSbO}_{7}$ revealed that $\mathrm{Fe}_{2} \mathrm{BiSbO}_{7}$ was pure phase without any other impure elements and $\mathrm{Fe}_{2} \mathrm{BiSbO}_{7}$ displayed the presence of iron, bismuth, antimony, and oxygen. It could be seen from Figure 1 that $\mathrm{Fe}_{2} \mathrm{BiSbO}_{7}$ was crystallized with the pyrochloretype structure, cubic crystal system, and space group $\mathrm{Fd} 3 \mathrm{~m}$. The lattice parameter for $\mathrm{Fe}_{2} \mathrm{BiSbO}_{7}$ was proved to be $a=10.410297 \AA$. According to the calculation results from Figure 1, the (h k l) value for the main peaks of $\mathrm{Fe}_{2} \mathrm{BiSbO}_{7}$ could be found and indexed.

Full-profile structure refinements of the collected X-ray diffraction data of $\mathrm{Fe}_{2} \mathrm{BiSbO}_{7}$ were obtained by the RIETAN [34] program, which was based on Pawley analysis. The refinement results of $\mathrm{Fe}_{2} \mathrm{BiSbO}_{7}$ are shown in Figure 2. The atomic coordinates and structural parameters of $\mathrm{Fe}_{2} \mathrm{BiSbO}_{7}$ are listed in Table 1. The results of the final refinement for $\mathrm{Fe}_{2} \mathrm{BiSbO}_{7}$ indicated a good agreement between the observed and calculated intensities in a pyrochlore-type structure and cubic crystal system with space group $\mathrm{Fd} 3 \mathrm{~m}$. Our XRD results also showed that $\mathrm{Fe}_{2} \mathrm{BiSbO}_{7}$ and $\mathrm{Bi}_{2} \mathrm{InTaO}_{7}$ were crystallized in the same structure, and 2 theta angles of each reflection of $\mathrm{Fe}_{2} \mathrm{BiSbO}_{7}$ changed with $\mathrm{Fe}^{3+}$ being replaced by $\mathrm{Bi}^{3+}, \mathrm{Bi}^{3+}$ being replaced by $\mathrm{In}^{3+}$, and $\mathrm{Sb}^{5+}$ being replaced by $\mathrm{Ta}^{5+}$. $\mathrm{Bi}_{2} \mathrm{InTaO}_{7}$ was also crystallized with a cubic structure by space group $\mathrm{Fd} 3 \mathrm{~m}$ and the lattice parameter of $\mathrm{Bi}_{2} \mathrm{InTaO}_{7}$ was $a=10.746410 \AA$. The lattice parameter of $\mathrm{Fe}_{2} \mathrm{BiSbO}_{7}$ was $a=10.410297 \AA$, which indicated that the lattice parameter of $\mathrm{Fe}_{2} \mathrm{BiSbO}_{7}$ decreased compared with the lattice parameter of $\mathrm{Bi}_{2} \mathrm{InTaO}_{7}$ because the $\mathrm{In}^{3+}$ ionic radii $(0.92 \AA)$ or the $\mathrm{Bi}^{3+}$ ionic radii $(1.17 \AA)$ was larger than the $\mathrm{Fe}^{3+}$ ionic radii $(0.78 \AA)$. The outcome of refinement for $\mathrm{Fe}_{2} \mathrm{BiSbO}_{7}$ generated the unweighted $R$ factor, $R_{P}=$ $11.56 \%$ with space group $F d 3 m$. Zou et al. [35] refined the crystal structure of $\mathrm{Bi}_{2} \mathrm{InNbO}_{7}$ and obtained a large $R$ factor for $\mathrm{Bi}_{2} \mathrm{InNbO}_{7}$, which was ascribed to a slightly modified structure model for $\mathrm{Bi}_{2} \mathrm{InNbO}_{7}$. Based on the high purity of the precursors which were used in this study and the EDS results that did not trace any other elements, it was unlikely that the observed space groups originated from the presence of impurities. Therefore, it was suggested that the slightly high $R$ factor for $\mathrm{Fe}_{2} \mathrm{BiSbO}_{7}$ was due to a slightly modified 


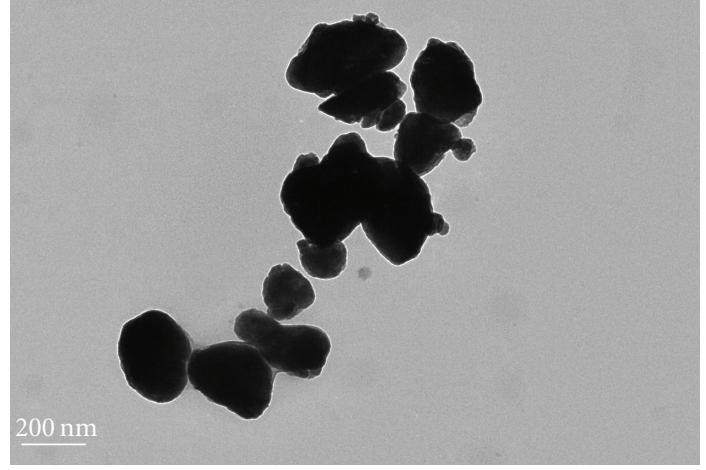

(a)

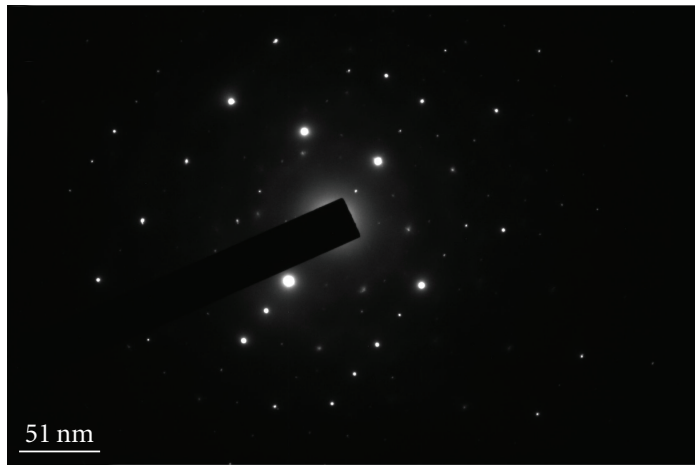

(b)

FIgURE 1: TEM image of $\mathrm{Fe}_{2} \mathrm{BiSbO}_{7}$ (a) and the selected area electron diffraction pattern of $\mathrm{Fe}_{2} \mathrm{BiSbO}_{7}$ (b).

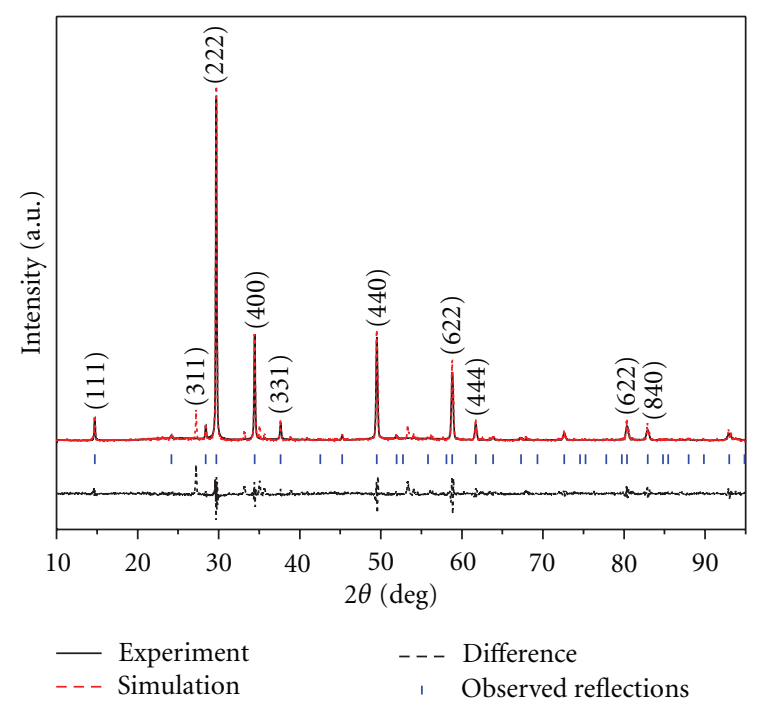

FIGURE 2: Pawley refinements of XRD data for novel photocatalyst $\mathrm{Fe}_{2} \mathrm{BiSbO}_{7}$ prepared by the solid state reaction method at $1020^{\circ} \mathrm{C}$. The solid line represents experimental X-ray diffraction pattern (-). The dot line represents simulation X-ray diffraction pattern (...). The tic marks represent reflection positions. A difference (observed-calculated) profile is shown beneath.

TABle 1: Atomic coordinates and structural parameters of $\mathrm{Fe}_{2} \mathrm{BiSbO}_{7}$ prepared by the solid state reaction method.

\begin{tabular}{lcccc}
\hline Atom & $x$ & $y$ & $z$ & Occupation factor \\
\hline $\mathrm{Fe}$ & 0.00000 & 0.00000 & 0.00000 & 1.0 \\
$\mathrm{Bi}$ & 0.50000 & 0.50000 & 0.50000 & 0.5 \\
$\mathrm{Sb}$ & 0.50000 & 0.50000 & 0.50000 & 0.5 \\
$\mathrm{O}(1)$ & -0.14538 & 0.12500 & 0.12500 & 1.0 \\
$\mathrm{O}(2)$ & 0.12500 & 0.12500 & 0.12500 & 1.0 \\
\hline
\end{tabular}

structure model for $\mathrm{Fe}_{2} \mathrm{BiSbO}_{7}$. It should be emphasized that the defects or the disorder/order of a fraction of the atoms could result in the change of structures, including different bond-distance distributions, thermal displacement parameters, and/or occupation factors for some of the atoms.

In order to reveal the surface chemical compositions and the valence states of various elements of $\mathrm{Fe}_{2} \mathrm{BiSbO}_{7}$, the X-ray
TABLE 2: Binding energies (BE) for key elements from $\mathrm{Fe}_{2} \mathrm{BiSbO}_{7}$.

\begin{tabular}{lllll}
\hline \multirow{2}{*}{ Compounds } & $\mathrm{Bi}_{4 \mathrm{f} 7 / 2}$ & $\mathrm{Sb}_{3 \mathrm{~d} 5 / 2}$ & $\mathrm{Fe}_{2 \mathrm{p} 3 / 2}$ & $\mathrm{O}_{1 \mathrm{~s}}$ \\
& $\mathrm{BE}(\mathrm{eV})$ & $\mathrm{BE}(\mathrm{eV})$ & $\mathrm{BE}(\mathrm{eV})$ & $\mathrm{BE}(\mathrm{eV})$ \\
\hline $\mathrm{Fe}_{2} \mathrm{BiSbO}_{7}$ & 155.80 & 530.88 & 708.10 & 527.00 \\
\hline
\end{tabular}

photoelectron spectrum of $\mathrm{Fe}_{2} \mathrm{BiSbO}_{7}$ for detecting $\mathrm{Fe}$, $\mathrm{Bi}$, $\mathrm{Sb}$, and $\mathrm{O}$ was performed. The full XPS spectrum confirmed that the prepared $\mathrm{Fe}_{2} \mathrm{BiSbO}_{7}$ contained elements of $\mathrm{Fe}, \mathrm{Bi}$, $\mathrm{Sb}$, and $\mathrm{O}$, which was consistent with the results of SEMEDS. The different elemental peaks which are corresponding to definite binding energies are given in Table 2 . The results illustrated that the oxidation states of $\mathrm{Fe}, \mathrm{Bi}, \mathrm{Sb}$, and $\mathrm{O}$ ions from $\mathrm{Fe}_{2} \mathrm{BiSbO}_{7}$ were $+3,+3,+5$, and -2 , respectively. Besides, the average atomic ratio of $\mathrm{Fe}: \mathrm{Bi}: \mathrm{Sb}: \mathrm{O}$ for $\mathrm{Fe}_{2} \mathrm{BiSbO}_{7}$ was $2.00: 0.97: 1.01: 6.98$ based on our XPS, SEM-EDS and XFS results. Accordingly, it could be deduced that the resulting material was highly pure under our preparation conditions. It was remarkable that there were not any shoulders and widening in the XPS peaks of $\mathrm{Fe}_{2} \mathrm{BiSbO}_{7}$, which suggested the absence of any other phases.

3.2. Photocatalytic Properties. Generally, the direct absorption of band-gap photons would result in the generation of electron-hole pairs within $\mathrm{Fe}_{2} \mathrm{BiSbO}_{7}$, subsequently; the charge carriers began to diffuse to the surface of $\mathrm{Fe}_{2} \mathrm{BiSbO}_{7}$. As a result, the photocatalytic activity for decomposing organic compounds with $\mathrm{Fe}_{2} \mathrm{BiSbO}_{7}$ might be enhanced. Changes in the UV-Vis spectrum of MB upon exposure to visible light $(\lambda>400 \mathrm{~nm})$ irradiation with the presence of $\mathrm{Fe}_{2} \mathrm{BiSbO}_{7}, \mathrm{Bi}_{2} \mathrm{InTaO}_{7}$, or $\mathrm{N}$-doped $\mathrm{TiO}_{2}$ indicated that $\mathrm{Fe}_{2} \mathrm{BiSbO}_{7}, \mathrm{Bi}_{2} \mathrm{InTaO}_{7}$, or N-doped $\mathrm{TiO}_{2}$ could photodegrade $\mathrm{MB}$ effectively under visible light irradiation. Figure 3 shows the photocatalytic degradation of methylene blue under visible light irradiation in the presence of $\mathrm{Fe}_{2} \mathrm{BiSbO}_{7}$, $\mathrm{Bi}_{2} \mathrm{InTaO}_{7}$, pure $\mathrm{TiO}_{2}, \mathrm{~N}$-doped $\mathrm{TiO}_{2}$, as well as in the absence of a photocatalyst. The results showed that a reduction in typical MB peaks at $665 \mathrm{~nm}$ and $614.5 \mathrm{~nm}$ was clearly noticed and the photodegradation rate of $\mathrm{MB}$ was about $1.980 \times 10^{-9} \mathrm{~mol} \mathrm{~L}^{-1} \mathrm{~s}^{-1}$ and the photonic efficiency was estimated to be $0.0416 \%(\lambda=420 \mathrm{~nm})$ with $\mathrm{Fe}_{2} \mathrm{BiSbO}_{7}$ 
as catalyst. Similarly, the photodegradation rate of $\mathrm{MB}$ was about $1.001 \times 10^{-9} \mathrm{~mol} \mathrm{~L}^{-1} \mathrm{~s}^{-1}$ and the photonic efficiency was estimated to be $0.0210 \%(\lambda=420 \mathrm{~nm})$ with $\mathrm{N}$-doped $\mathrm{TiO}_{2}$ as catalyst. Moreover, the photodegradation rate of MB was about $0.891 \times 10^{-9} \mathrm{~mol} \mathrm{~L}^{-1} \mathrm{~s}^{-1}$ and the photonic efficiency was estimated to be $0.0187 \%(\lambda=420 \mathrm{~nm})$ with $\mathrm{Bi}_{2} \mathrm{InTaO}_{7}$ as catalyst. By contrast, the photodegradation rate of MB within 200 min of visible light irradiation was only $0.8338 \times 10^{-9} \mathrm{~mol} \mathrm{~L}^{-1} \mathrm{~s}^{-1}$ and the photonic efficiency was estimated to be $0.0175 \%(\lambda=420 \mathrm{~nm})$ with pure $\mathrm{TiO}_{2}$ as catalyst. The photodegradation rate of MB was about $0.6830 \times$ $10^{-9} \mathrm{~mol} \mathrm{~L}^{-1} \mathrm{~s}^{-1}$ and the photonic efficiency was estimated to be $0.0143 \%(\lambda=420 \mathrm{~nm})$ in the absence of a photocatalyst. The results showed that the photodegradation rate of $\mathrm{MB}$ and the photonic efficiency with $\mathrm{Fe}_{2} \mathrm{BiSbO}_{7}$ as catalyst were both higher than those with $\mathrm{N}$-doped $\mathrm{TiO}_{2}$ or $\mathrm{Bi}_{2} \mathrm{InTaO}_{7}$, or pure $\mathrm{TiO}_{2}$ as catalyst. The photodegradation rate of $\mathrm{MB}$ and the photonic efficiency with $\mathrm{N}$-doped $\mathrm{TiO}_{2}$ as catalyst were both higher than those with $\mathrm{Bi}_{2} \mathrm{InTaO}_{7}$ or pure $\mathrm{TiO}_{2}$ as catalyst. The photodegradation rate of $\mathrm{MB}$ and the photonic efficiency with $\mathrm{Bi}_{2} \mathrm{InTaO}_{7}$ as catalyst were both higher than those with pure $\mathrm{TiO}_{2}$ or the absence of a photocatalyst. The photodegradation rate of $\mathrm{MB}$ and the photonic efficiency with pure $\mathrm{TiO}_{2}$ as catalyst were both higher than those with the absence of a photocatalyst. When $\mathrm{Fe}_{2} \mathrm{BiSbO}_{7}, \mathrm{~N}$-doped $\mathrm{TiO}_{2}, \mathrm{Bi}_{2} \mathrm{InTaO}_{7}$ or pure $\mathrm{TiO}_{2}$ was used as photocatalyst, the photodegradation conversion rate of $\mathrm{MB}$ was $96.59 \%$, $48.05 \%, 42.76 \%$, and $40.02 \%$ after visible light irradiation for $200 \mathrm{~min}$, respectively. Moreover, the photodegradation conversion rate of $\mathrm{MB}$ was $32.78 \%$ after visible light irradiation for 200 min with the absence of a photocatalyst because of the MB dye photosensitization effect [36]. After visible light irradiation for 230 min with $\mathrm{Fe}_{2} \mathrm{BiSbO}_{7}$ as catalyst, complete removal of $\mathrm{MB}$ was observed and the complete disappearance of the absorption peaks which presented the absolute color change from deep blue into colorless solution occurred. Based on above results, the photocatalytic degradation activity of $\mathrm{Fe}_{2} \mathrm{BiSbO}_{7}$ was much higher than that of $\mathrm{N}$ doped $\mathrm{TiO}_{2}, \mathrm{Bi}_{2} \mathrm{InTaO}_{7}$, or pure $\mathrm{TiO}_{2}$. Meanwhile, $\mathrm{N}$-doped $\mathrm{TiO}_{2}$ showed higher photocatalytic degradation activity for MB photodegradation compared with $\mathrm{Bi}_{2} \mathrm{InTaO}_{7}$ or pure $\mathrm{TiO}_{2} \cdot \mathrm{Bi}_{2} \mathrm{InTaO}_{7}$ showed higher photocatalytic degradation activity for $\mathrm{MB}$ photodegradation compared with pure $\mathrm{TiO}_{2}$. Pure $\mathrm{TiO}_{2}$ was more suitable for $\mathrm{MB}$ photodegradation than the absence of a photocatalyst. The photocatalytic property of novel $\mathrm{Fe}_{2} \mathrm{BiSbO}_{7}$ under visible light irradiation was amazing compared with that of $\mathrm{N}$-doped $\mathrm{TiO}_{2}$ or pure $\mathrm{TiO}_{2}$, and the main reason was that the specific surface area of $\mathrm{Fe}_{2} \mathrm{BiSbO}_{7}$ was much smaller than that of $\mathrm{N}$ doped $\mathrm{TiO}_{2}$ or pure $\mathrm{TiO}_{2}$. BET isotherm measurements of $\mathrm{Fe}_{2} \mathrm{BiSbO}_{7}, \mathrm{~N}$-doped $\mathrm{TiO}_{2}$, and pure $\mathrm{TiO}_{2}$ provided a specific surface area of $2.78 \mathrm{~m}^{2} \mathrm{~g}^{-1}, 45.53 \mathrm{~m}^{2} \mathrm{~g}^{-1}$, and $46.24 \mathrm{~m}^{2} \mathrm{~g}^{-1}$, respectively, which indicated that the photocatalytic degradation activity of $\mathrm{Fe}_{2} \mathrm{BiSbO}_{7}$ could be greatly improved by enhancing the specific surface area of $\mathrm{Fe}_{2} \mathrm{BiSbO}_{7}$.

Figure 4 shows the change of TOC during photocatalytic degradation of $\mathrm{MB}$ with $\mathrm{Fe}_{2} \mathrm{BiSbO}_{7}, \mathrm{Bi}_{2} \mathrm{InTaO}_{7}$, or $\mathrm{N}$ doped $\mathrm{TiO}_{2}$ as catalyst under visible light irradiation. The TOC measurements revealed the disappearance of organic

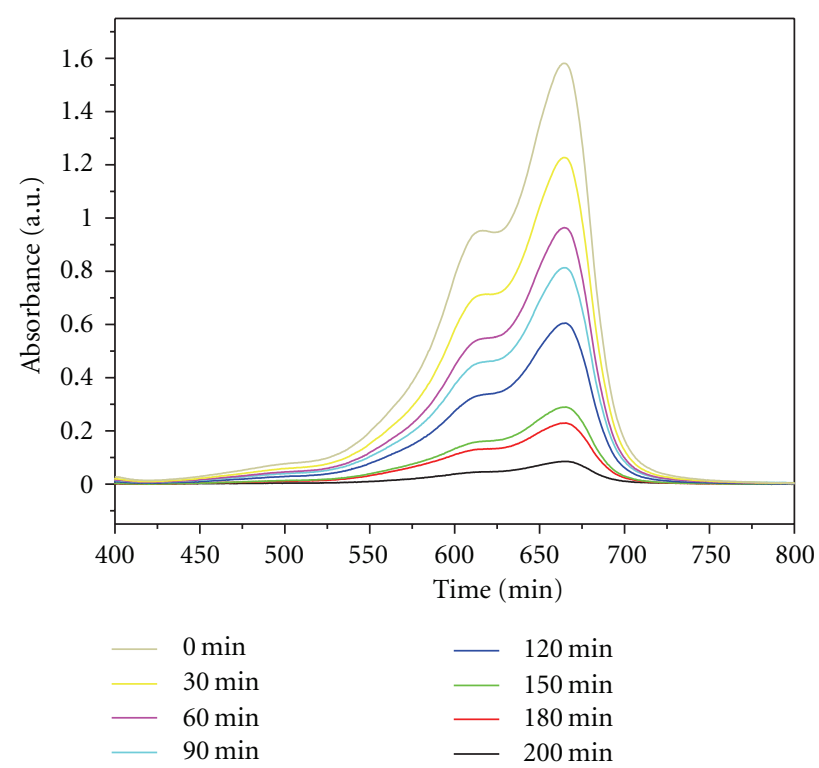

(a)

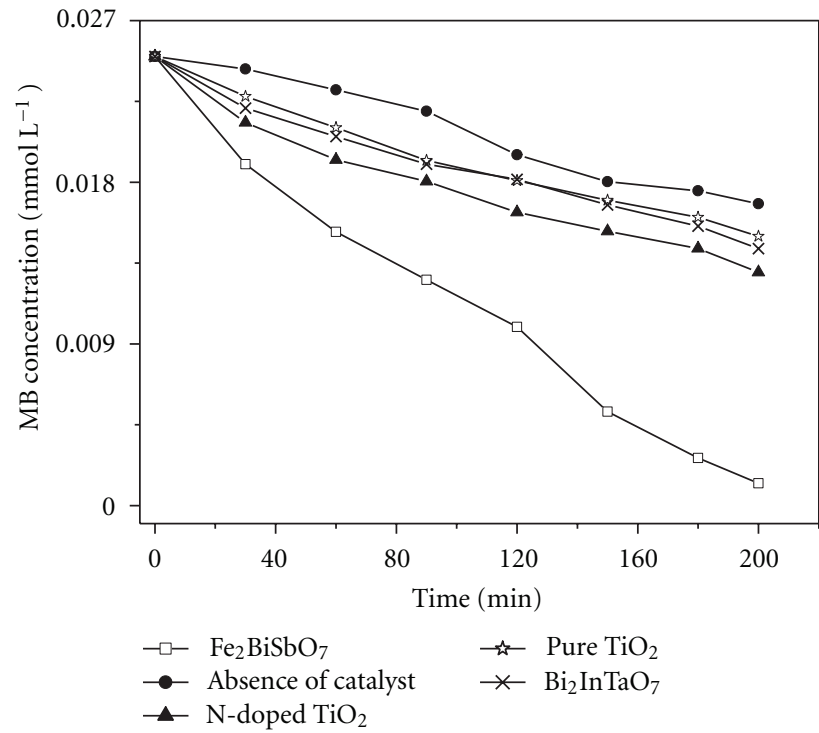

(b)

FIGURE 3: The absorbance pattern of methylene blue photocatalytically degraded by $\mathrm{Fe}_{2} \mathrm{BiSbO}_{7}$ (a), and photocatalytic degradation of methylene blue under visible light irradiation in the presence of $\mathrm{Fe}_{2} \mathrm{BiSbO}_{7}, \mathrm{Bi}_{2} \mathrm{InTaO}_{7}$, pure $\mathrm{TiO}_{2}, \mathrm{~N}$-doped $\mathrm{TiO}_{2}$, as well as in the absence of a photocatalyst (b).

carbon when the $\mathrm{MB}$ solution which contained $\mathrm{Fe}_{2} \mathrm{BiSbO}_{7}$, $\mathrm{Bi}_{2} \mathrm{InTaO}_{7}$, or $\mathrm{N}$-doped $\mathrm{TiO}_{2}$ was exposed under visible light irradiation. The results showed that $89.51 \%, 46.77 \%$, or $41.71 \%$ of TOC decrease was obtained after visible light irradiation for 200 min when $\mathrm{Fe}_{2} \mathrm{BiSbO}_{7}$, or N-doped $\mathrm{TiO}_{2}$ or $\mathrm{Bi}_{2} \mathrm{InTaO}_{7}$ was used as photocatalyst. Consequently, after visible light irradiation for 230 min with $\mathrm{Fe}_{2} \mathrm{BiSbO}_{7}$ as catalyst, the entire mineralization of $\mathrm{MB}$ was observed because of $100 \%$ TOC removal. The turnover number which represented the ratio between the total amount of evolved gas and dissipative catalyst was calculated to be more than 0.204 for 


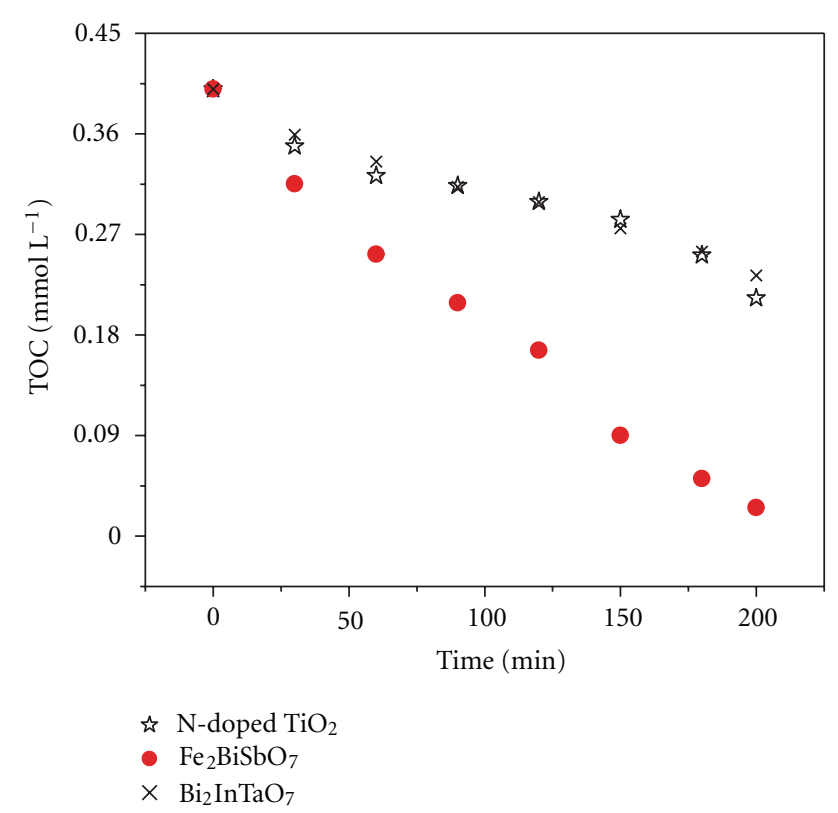

FIgURe 4: Disappearance of total organic carbon (TOC) during photocatalytic degradation of methylene blue with $\mathrm{Fe}_{2} \mathrm{BiSbO}_{7}$, $\mathrm{Bi}_{2} \mathrm{InTaO}_{7}$, or $\mathrm{N}$-doped $\mathrm{TiO}_{2}$ as catalyst under visible light irradiation.

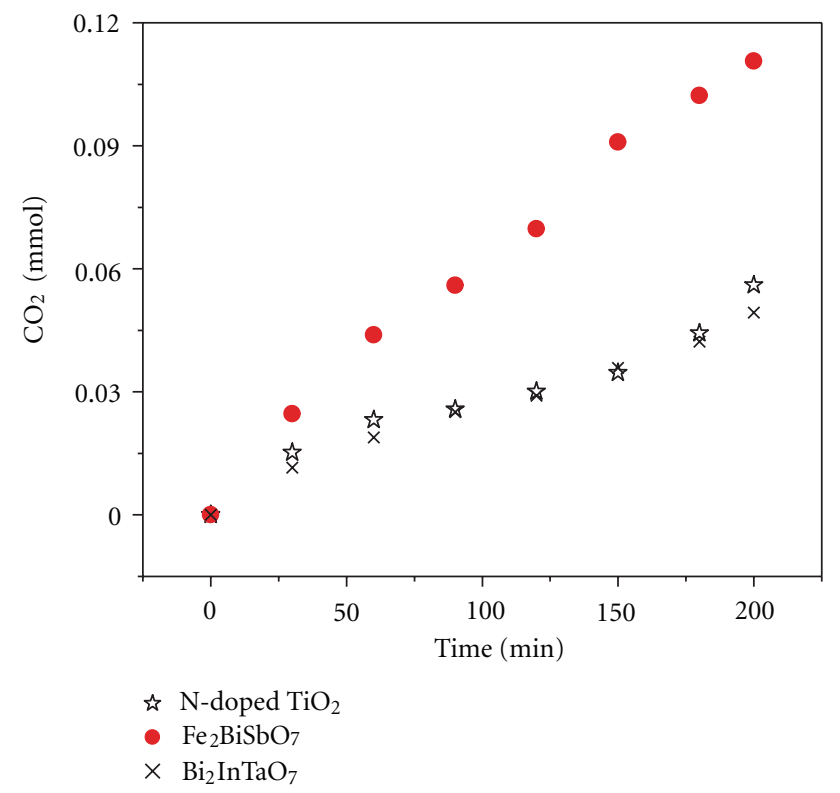

Figure 5: $\mathrm{CO}_{2}$ production kinetics during the photocatalytic degradation of methylene blue with $\mathrm{Fe}_{2} \mathrm{BiSbO}_{7}, \mathrm{Bi}_{2} \mathrm{InTaO}_{7}$, or Ndoped $\mathrm{TiO}_{2}$ as catalyst under visible light irradiation.

$\mathrm{Fe}_{2} \mathrm{BiSbO}_{7}$ after 200 min of reaction time under visible light irradiation and this turnover number was evident to prove that this reaction occurred catalytically. Similarly, when the light was turned off in this experiment, the stop of this reaction showed the obvious light response.

Figure 5 shows the amount of $\mathrm{CO}_{2}$ which was yielded during the photodegradation of $\mathrm{MB}$ with $\mathrm{Fe}_{2} \mathrm{BiSbO}_{7}$, $\mathrm{Bi}_{2} \mathrm{InTaO}_{7}$ or $\mathrm{N}$-doped $\mathrm{TiO}_{2}$ as catalyst under visible light irradiation. The amount of $\mathrm{CO}_{2}$ increased gradually with increasing reaction time when $\mathrm{MB}$ was photodegraded by $\mathrm{Fe}_{2} \mathrm{BiSbO}_{7}, \mathrm{Bi}_{2} \mathrm{InTaO}_{7}$ or $\mathrm{N}$-doped $\mathrm{TiO}_{2}$. At the same time, after $200 \mathrm{~min}$ visible light irradiation, the $\mathrm{CO}_{2}$ production of $0.11063 \mathrm{mmol}$ with $\mathrm{Fe}_{2} \mathrm{BiSbO}_{7}$ as catalyst was higher than the $\mathrm{CO}_{2}$ production of $0.05600 \mathrm{mmol}$ with $\mathrm{N}$-doped $\mathrm{TiO}_{2}$ as catalyst. Meanwhile, after visible light irradiation for $200 \mathrm{~min}$, the $\mathrm{CO}_{2}$ production of $0.05600 \mathrm{mmol}$ with $\mathrm{N}$ doped $\mathrm{TiO}_{2}$ as catalyst was higher than the $\mathrm{CO}_{2}$ production of $0.04934 \mathrm{mmol}$ with $\mathrm{Bi}_{2} \mathrm{InTaO}_{7}$ as catalyst.

The first-order nature of the photocatalytic degradation kinetics with $\mathrm{Fe}_{2} \mathrm{BiSbO}_{7}, \mathrm{Bi}_{2} \mathrm{InTaO}_{7}$, or $\mathrm{N}$-doped $\mathrm{TiO}_{2}$ as catalyst is clearly demonstrated in Figure 6. The results showed a linear correlation between $\ln \left(C / C_{o}\right)$ (or $\ln \left(\mathrm{TOC}^{\mathrm{T}} \mathrm{TOC}_{\mathrm{o}}\right)$ ) and the irradiation time for the photocatalytic degradation of $\mathrm{MB}$ under visible light irradiation with the presence of $\mathrm{Fe}_{2} \mathrm{BiSbO}_{7}, \mathrm{Bi}_{2} \mathrm{InTaO}_{7}$, or N-doped $\mathrm{TiO}_{2}$. Here, $C$ represented the $\mathrm{MB}$ concentration at time $t, C_{o}$ represented the initial $\mathrm{MB}$ concentration, TOC represented the total organic carbon concentration at time $t$, and $\mathrm{TOC}_{o}$ represented the initial total organic carbon concentration. According to Figure 6 , the first-order rate constant $k_{C}$ of $\mathrm{MB}$ concentration was estimated to be $0.01189 \mathrm{~min}^{-1}$ with $\mathrm{Fe}_{2} \mathrm{BiSbO}_{7}$ as catalyst, $0.00275 \mathrm{~min}^{-1}$ with $\mathrm{Bi}_{2} \mathrm{InTaO}_{7}$ as catalyst, and $0.00333 \mathrm{~min}^{-1}$ with $\mathrm{N}$-doped $\mathrm{TiO}_{2}$ as catalyst. The different value of $k_{C}$ indicated that $\mathrm{Fe}_{2} \mathrm{BiSbO}_{7}$ was more suitable for the photocatalytic degradation of $\mathrm{MB}$ under visible light irradiation than $\mathrm{N}$-doped $\mathrm{TiO}_{2}$ or $\mathrm{Bi}_{2} \mathrm{InTaO}_{7}$. Meanwhile Ndoped $\mathrm{TiO}_{2}$ was more suitable for the photocatalytic degradation of $\mathrm{MB}$ under visible light irradiation than $\mathrm{Bi}_{2} \mathrm{InTaO}_{7}$. Figure 6 also showed that the first-order rate constant $K_{\text {TOC }}$ of TOC was estimated to be $0.01101 \mathrm{~min}^{-1}$ with $\mathrm{Fe}_{2} \mathrm{BiSbO}_{7}$ as catalyst, $0.00275 \mathrm{~min}^{-1}$ with $\mathrm{N}$-doped $\mathrm{TiO}_{2}$ as catalyst, and $0.00259 \mathrm{~min}^{-1}$ with $\mathrm{Bi}_{2} \mathrm{InTaO}_{7}$ as catalyst, which indicated that the photodegradation intermediate products of $\mathrm{MB}$ probably appeared during the photocatalytic degradation of $\mathrm{MB}$ under visible light irradiation because of the different value between $k_{C}$ and $K_{\mathrm{TOC}}$. It could also be seen from Figure 6 that $\mathrm{Fe}_{2} \mathrm{BiSbO}_{7}$ showed higher mineralization efficiency for $\mathrm{MB}$ degradation compared with $\mathrm{N}$-doped $\mathrm{TiO}_{2}$ or $\mathrm{Bi}_{2} \mathrm{InTaO}_{7}$. At the same time, $\mathrm{N}$-doped $\mathrm{TiO}_{2}$ showed higher mineralization efficiency for $\mathrm{MB}$ degradation compared with $\mathrm{Bi}_{2} \mathrm{InTaO}_{7}$.

Some inorganic ions such as $\mathrm{NH}_{4}{ }^{+}, \mathrm{NO}_{3}{ }^{-}$, and $\mathrm{SO}_{4}{ }^{2-}$ were formed in parallel as the end products of nitrogen and sulfur atoms which existed in MB. Figures 7 and 8 showed the concentration variation of $\mathrm{SO}_{4}{ }^{2-}$ and $\mathrm{NO}_{3}{ }^{-}$during photocatalytic degradation of $\mathrm{MB}$ with $\mathrm{Fe}_{2} \mathrm{BiSbO}_{7}, \mathrm{Bi}_{2} \mathrm{InTaO}_{7}$, or $\mathrm{N}$-doped $\mathrm{TiO}_{2}$ as catalyst under visible light irradiation. The results showed that the concentration of $\mathrm{NO}_{3}{ }^{-}$or $\mathrm{SO}_{4}{ }^{2-}$ increased gradually with increasing reaction time when $\mathrm{MB}$ was photodegraded by $\mathrm{Fe}_{2} \mathrm{BiSbO}_{7}, \mathrm{Bi}_{2} \mathrm{InTaO}_{7}$, or $\mathrm{N}$-doped $\mathrm{TiO}_{2}$. Monitoring the presence of ions in the solution revealed that the $\mathrm{SO}_{4}{ }^{2-}$ ion concentration was $0.01849 \mathrm{mM}$, $0.00924 \mathrm{mM}$, or $0.00757 \mathrm{mM}$ with $\mathrm{Fe}_{2} \mathrm{BiSbO}_{7}, \mathrm{~N}$-doped $\mathrm{TiO}_{2}$, or $\mathrm{Bi}_{2} \mathrm{InTaO}_{7}$ as catalyst after visible light irradiation for $200 \mathrm{~min}$, indicating that $63.22 \%, 36.94 \%$, or $30.28 \%$ of sulfur from $\mathrm{MB}$ was converted into sulfate ions with $\mathrm{Fe}_{2} \mathrm{BiSbO}_{7}, \mathrm{~N}$-doped $\mathrm{TiO}_{2}$, or $\mathrm{Bi}_{2} \mathrm{InTaO}_{7}$ as catalyst after 


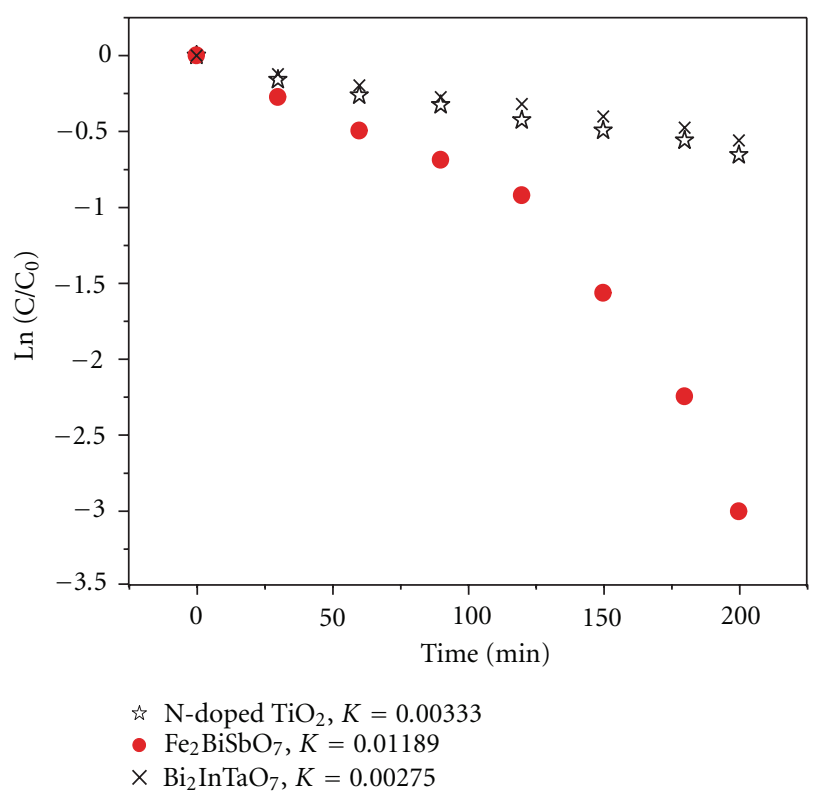

(a)

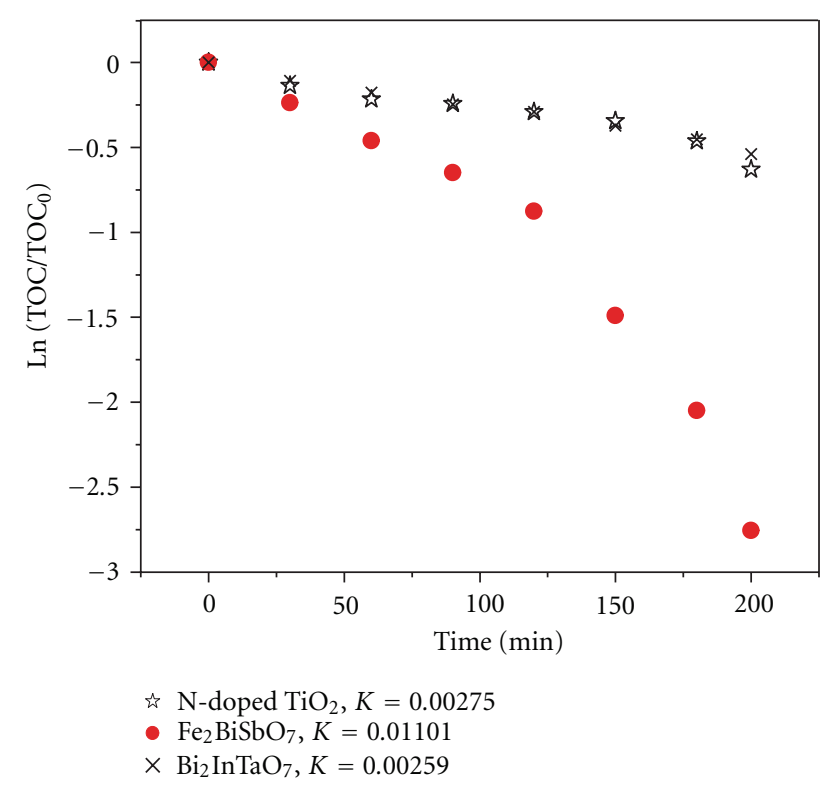

(b)

Figure 6: Observed first-order kinetic plots for the photocatalytic degradation of methylene blue with $\mathrm{Fe}_{2} \mathrm{BiSbO}_{7}, \mathrm{Bi}_{2} \mathrm{InTaO}_{7}$, or Ndoped $\mathrm{TiO}_{2}$ as catalyst under visible light irradiation.

visible light irradiation for $200 \mathrm{~min}$. It could be seen from Figure 8 that the $\mathrm{NO}_{3}{ }^{-}$ion concentration was $0.05258 \mathrm{mM}$, $0.0351 \mathrm{mM}$, or $0.02232 \mathrm{mM}$ with $\mathrm{Fe}_{2} \mathrm{BiSbO}_{7}, \mathrm{~N}$-doped $\mathrm{TiO}_{2}$, or $\mathrm{Bi}_{2} \mathrm{InTaO}_{7}$ as catalyst after visible light irradiation for $200 \mathrm{~min}$, which indicated that $70.11 \%, 46.80 \%$, or $29.76 \%$ of nitrogen from $\mathrm{MB}$ was converted into nitrate ions with $\mathrm{Fe}_{2} \mathrm{BiSbO}_{7}, \mathrm{~N}$-doped $\mathrm{TiO}_{2}$, or $\mathrm{Bi}_{2} \mathrm{InTaO}_{7}$ as catalyst after visible light irradiation for $200 \mathrm{~min}$. The sulfur was first hydrolytically removed, and subsequently was oxidized and transformed into $\mathrm{SO}_{4}{ }^{2-}$. At the same time, nitrogen atoms

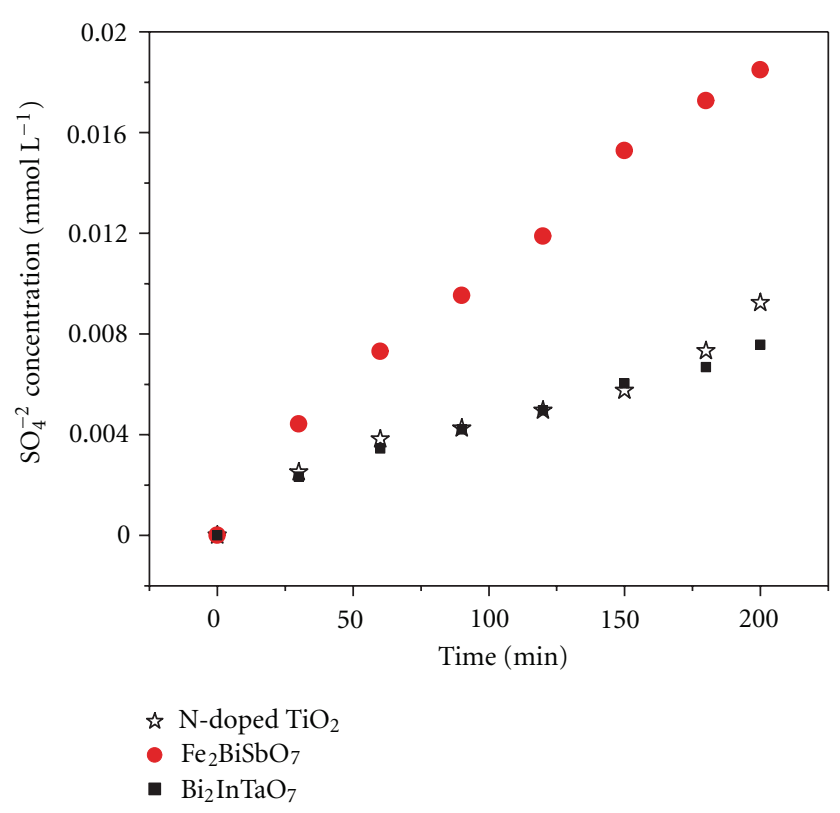

FIGURE 7: The concentration variation of $\mathrm{SO}_{4}{ }^{2-}$ during photocatalytic degradation of methylene blue with $\mathrm{Fe}_{2} \mathrm{BiSbO}_{7}, \mathrm{Bi}_{2} \mathrm{InTaO}_{7}$, or $\mathrm{N}$-doped $\mathrm{TiO}_{2}$ as catalyst under visible light irradiation.

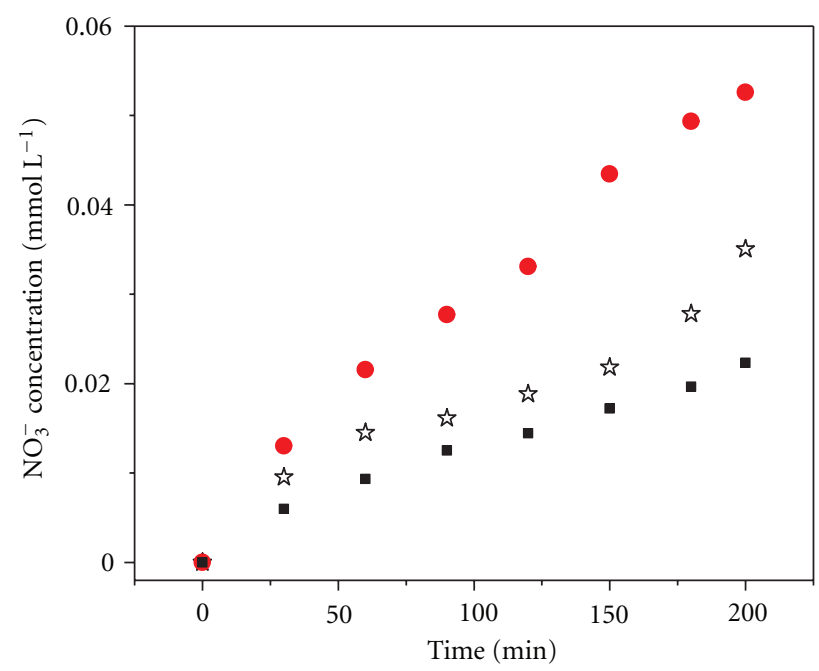

N-doped $\mathrm{TiO}_{2}$
- $\mathrm{Fe}_{2} \mathrm{BiSbO}_{7}$
- $\mathrm{Bi}_{2} \mathrm{InTaO}_{7}$

FIGURE 8: The concentration variation of $\mathrm{NO}_{3}{ }^{-}$during photocatalytic degradation of methylene blue with $\mathrm{Fe}_{2} \mathrm{BiSbO}_{7}, \mathrm{Bi}_{2} \mathrm{InTaO}_{7}$, or $\mathrm{N}$-doped $\mathrm{TiO}_{2}$ as catalyst under visible light irradiation.

in the -3 oxidation state produced $\mathrm{NH}_{4}{ }^{+}$cations that subsequently were oxidized into $\mathrm{NO}_{3}{ }^{-}$ions. As expected, the formation kinetics with $\mathrm{Fe}_{2} \mathrm{BiSbO}_{7}$ was significantly faster than that of $\mathrm{N}$-doped $\mathrm{TiO}_{2}$ or $\mathrm{Bi}_{2} \mathrm{InTaO}_{7}$ by using the same amount of photocatalyst. Moreover, the formation kinetics with $\mathrm{N}$-doped $\mathrm{TiO}_{2}$ was faster than that of $\mathrm{Bi}_{2} \mathrm{InTaO}_{7}$ by using the same amount of photocatalyst. It was noteworthy 


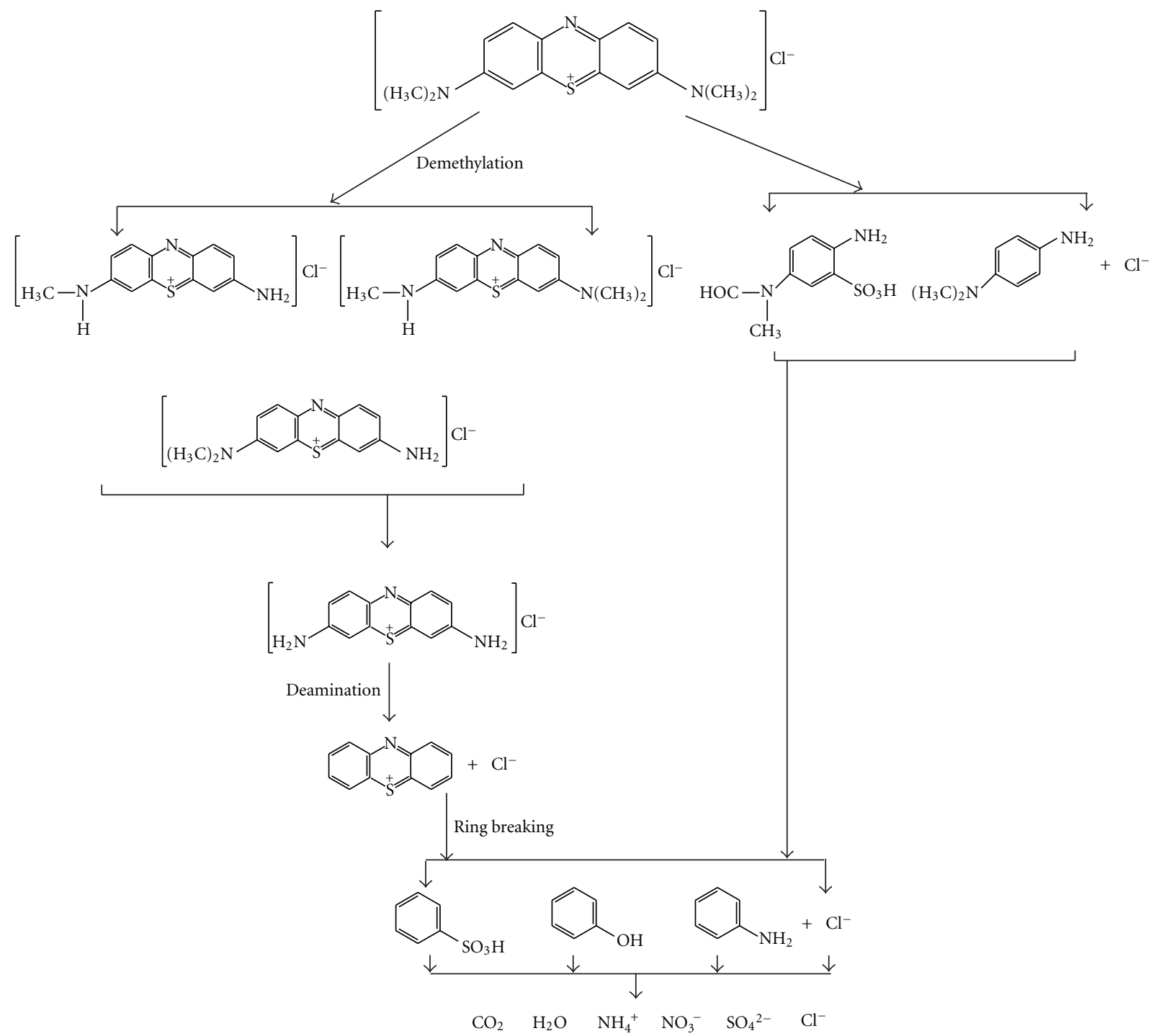

FIGURE 9: Suggested photocatalytic degradation pathway scheme for methylene blue under visible light irradiation in the presence of $\mathrm{Fe}_{2} \mathrm{BiSbO}_{7}$.

that the amount of $\mathrm{SO}_{4}{ }^{2-}$ ions which was released into the solution was lower than the amount of $\mathrm{SO}_{4}{ }^{2-}$ which should come from stoichiometry. One possible reason could be a loss of sulfur-containing volatile compounds such as $\mathrm{SO}_{2}$. The second possible reason was a partially irreversible adsorption of some $\mathrm{SO}_{4}{ }^{2-}$ ions on the surface of the photocatalyst which had been observed by Lachheb et al. by titanium dioxide [37]. Regardless, whether the sulfate ions were adsorbed irreversibly on the surface or not, it was important to stress that the evidence for restrained photocatalytic activity was not noticed.

The photodegradation intermediate products of $\mathrm{MB}$ in our experiment were identified as azure B, azure A, azure $\mathrm{C}$, thionine, phenothiazine, leucomethylene blue, $N, N$ dimethylp-phenylenediamine, phenol, and aniline. According to the intermediate products which were found in this work and the observed appearance time of other intermediate products, a possible photocatalytic degradation pathway for MB was proposed. Figure 9 shows the suggested photocatalytic degradation pathway scheme for methylene blue under visible light irradiation in the presence of $\mathrm{Fe}_{2} \mathrm{BiSbO}_{7}$. The molecule of $\mathrm{MB}$ was converted into small organic species, which were subsequently mineralized into inorganic products such as $\mathrm{SO}_{4}{ }^{2-}$ ions, $\mathrm{NO}_{3}{ }^{-}$ions, $\mathrm{CO}_{2}$, and water ultimately.

3.3. Photocatalytic Degradation Mechanism. The action spectra of $\mathrm{MB}$ degradation with $\mathrm{Fe}_{2} \mathrm{BiSbO}_{7}$ as catalyst were observed under visible light irradiation. A clear photonic efficiency $(0.0103 \%$ at its maximal point) at wavelengths which corresponded to sub-Eg energies of the photocatalysts ( $\lambda$ from 375 to $700 \mathrm{~nm}$ ) was observed for $\mathrm{Fe}_{2} \mathrm{BiSbO}_{7}$. The existence of photonic efficiency at this region revealed that photons are not absorbed by the photocatalysts. In particular, the correlation between the low-energy action spectrum and the absorption spectrum of MB clearly demonstrated that 
any photodegradation results at wavelengths above $545 \mathrm{~nm}$ should be attributed to photosensitization effect by the dye MB itself (Scheme I).

Scheme I. Consider

$$
\begin{gathered}
\mathrm{MB}_{\text {ads }} \stackrel{\text { Visible light }}{\longrightarrow} \mathrm{MB}_{\mathrm{ads}}^{*} \\
\mathrm{MB}_{\text {ads }}^{*}+\mathrm{Fe}_{2} \mathrm{BiSbO}_{7} \longrightarrow \mathrm{Fe}_{2} \mathrm{BiSbO}_{7}(\mathrm{e})+\mathrm{MB}_{\text {ads }}^{+} \\
\mathrm{Fe}_{2} \mathrm{BiSbO}_{7}(\mathrm{e})+\mathrm{O}_{2} \longrightarrow \mathrm{Fe}_{2} \mathrm{BiSbO}_{7}+\cdot \mathrm{O}_{2}{ }^{-}
\end{gathered}
$$

According to the mechanism which was shown in Scheme I, MB which was adsorbed on $\mathrm{Fe}_{2} \mathrm{BiSbO}_{7}$ was excited by visible light irradiation. Subsequently, an electron was injected from the excited $\mathrm{MB}$ to the conduction band of $\mathrm{Fe}_{2} \mathrm{BiSbO}_{7}$ where the electron was scavenged by molecular oxygen. Scheme I explained the results which were obtained with $\mathrm{Fe}_{2} \mathrm{BiSbO}_{7}$ as catalyst under visible light irradiation, where the photocatalyst $\mathrm{Fe}_{2} \mathrm{BiSbO}_{7}$ could serve to reduce recombination of photogenerated electrons and holes by scavenging of electrons [38].

Below the wavelength of $545 \mathrm{~nm}$, the situation was different. The results of photonic efficiency correlated well with the absorption spectra of $\mathrm{Fe}_{2} \mathrm{BiSbO}_{7}$. These results evidently showed that the mechanism which was responsible for the photodegradation of $\mathrm{MB}$ went through band gap excitation of $\mathrm{Fe}_{2} \mathrm{BiSbO}_{7}$. Despite the detailed experiments about the effect of oxygen and water were not performed, it was logical to presume that the mechanism in the first step was similar to the observed mechanism for $\mathrm{Fe}_{2} \mathrm{BiSbO}_{7}$ under suprabandgap irradiation, namely Scheme II.

Scheme II. Consider

$$
\begin{gathered}
\mathrm{Fe}_{2} \mathrm{BiSbO}_{7} \stackrel{\text { Visible light }}{\longrightarrow} h^{+}+\mathrm{e}^{-} \\
\mathrm{e}^{-}+\mathrm{O}_{2} \longrightarrow \cdot \mathrm{O}_{2}{ }^{-} \\
h^{+}+\mathrm{OH}^{-} \longrightarrow \cdot \mathrm{OH}
\end{gathered}
$$

According to first principles calculations, we deduced that the conduction band of $\mathrm{Fe}_{2} \mathrm{BiSbO}_{7}$ was composed of $\mathrm{Fe} 3 d$ and $\mathrm{Sb} 5 p$ orbital component, and the valence band of $\mathrm{Fe}_{2} \mathrm{BiSbO}_{7}$ was composed of $\mathrm{O} 2 p$ and $\mathrm{Bi} 6 s$ orbital component. $\mathrm{Fe}_{2} \mathrm{BiSbO}_{7}$ could produce electron-hole pairs by absorption of photons directly, and it indicated that enough energy which was larger than the band gap energy of $\mathrm{Fe}_{2} \mathrm{BiSbO}_{7}$ was necessary for the photocatalytic degradation process of MB.

Former luminescent studies had shown that the closer the $\mathrm{M}-\mathrm{O}-\mathrm{M}$ bond angle was $180^{\circ}$, the more delocalized was the excited state [39], as a result, the charge carriers could move more easily in the matrix. The mobility of the photoinduced electrons and holes influenced the photocatalytic activity because high diffusivity indicated the enhancement of probability that the photogenerated electrons and holes would reach the reactive sites of the catalyst surface. For $\mathrm{Fe}_{2} \mathrm{BiSbO}_{7}$, the bond angle of $\mathrm{Bi}-\mathrm{O}-\mathrm{Sb}$ was $119.76^{\circ}$, which indicated that the bond angle of $\mathrm{Bi}-\mathrm{O}-\mathrm{Sb}$ was close to $180^{\circ}$. Thus, the photocatalytic activity of $\mathrm{Fe}_{2} \mathrm{BiSbO}_{7}$ was consequently higher. The crystal structure and the electronic structure of $\mathrm{Fe}_{2} \mathrm{BiSbO}_{7}$ and $\mathrm{N}$-doped $\mathrm{TiO}_{2}$ were totally different. For $\mathrm{Fe}_{2} \mathrm{BiSbO}_{7}$, Fe was $3 d$-block metal element, and $\mathrm{Bi}$ was $6 p$ block metal element, and Sb was $5 p$-block metal element. But for $\mathrm{N}$-doped $\mathrm{TiO}_{2}$, Ti was $3 d$-block metal element, indicating that the photocatalytic activity might be affected by not only the crystal structure but also the electronic structure of the photocatalysts, as well. In conclusion, the different photodegradation effect of $\mathrm{MB}$ between $\mathrm{Fe}_{2} \mathrm{BiSbO}_{7}$ and Ndoped $\mathrm{TiO}_{2}$ could be mainly attributed to the difference of their crystalline structures and electronic structures.

The present results indicated that the $\mathrm{Fe}_{2} \mathrm{BiSbO}_{7}$-visible light photocatalysis system might be regarded as a practical method for treatment of diluted colored wastewater. This system could be utilized for decolorization, purification, and detoxification of textile, printing, and dyeing industries in the long-day countries. Meanwhile, this system did not need high pressure of oxygen, heating, or any chemical reagents. Much decolorized and detoxified water were flowed from our new system for treatment, and the results showed that the $\mathrm{Fe}_{2} \mathrm{BiSbO}_{7}$-visible light photocatalysis system might provide a valuable treatment for purifying and reusing colored aqueous effluents.

\section{Conclusions}

$\mathrm{Fe}_{2} \mathrm{BiSbO}_{7}$ was prepared by the solid-state reaction method for the first time. The structural and photocatalytic properties of $\mathrm{Fe}_{2} \mathrm{BiSbO}_{7}$ were investigated. XRD results indicated that $\mathrm{Fe}_{2} \mathrm{BiSbO}_{7}$ was crystallized with the pyrochlore-type structure, cubic crystal system, and space group $F d 3 m$. The lattice parameter of $\mathrm{Fe}_{2} \mathrm{BiSbO}_{7}$ was found to be $a=$ $10.410297 \AA$ A. Photocatalytic decomposition of aqueous MB was realized under visible light irradiation in the presence of $\mathrm{Fe}_{2} \mathrm{BiSbO}_{7}, \mathrm{Bi}_{2} \mathrm{InTaO}_{7}$, or $\mathrm{N}$-doped $\mathrm{TiO}_{2}$. The results showed that $\mathrm{Fe}_{2} \mathrm{BiSbO}_{7}$ owned higher catalytic activity compared with pure $\mathrm{TiO}_{2}, \mathrm{Bi}_{2} \mathrm{InTaO}_{7}$, or N-doped $\mathrm{TiO}_{2}$ for photocatalytic degradation of $\mathrm{MB}$ under visible light irradiation. The photocatalytic degradation of $\mathrm{MB}$ with $\mathrm{Fe}_{2} \mathrm{BiSbO}_{7}$, $\mathrm{Bi}_{2} \mathrm{InTaO}_{7}$, or $\mathrm{N}$-doped $\mathrm{TiO}_{2}$ as catalyst followed the firstorder reaction kinetics, and the first-order rate constant was $0.01189 \mathrm{~min}^{-1}, 0.00275 \mathrm{~min}^{-1}$, or $0.00333 \mathrm{~min}^{-1}$. Complete removal and mineralization of $\mathrm{MB}$ was observed after visible light irradiation for 230 min with $\mathrm{Fe}_{2} \mathrm{BiSbO}_{7}$ as catalyst. The reduction of the total organic carbon, the formation of inorganic products such as $\mathrm{SO}_{4}{ }^{2-}$ and $\mathrm{NO}_{3}{ }^{-}$, and the evolution of $\mathrm{CO}_{2}$ revealed the continuous mineralization of $\mathrm{MB}$ during the photocatalytic process. The possible photocatalytic degradation pathway of $\mathrm{MB}$ was obtained under visible light irradiation. $\mathrm{Fe}_{2} \mathrm{BiSbO}_{7} /$ (visible light) photocatalysis system was found to be suitable for textile industry wastewater treatment and could be used to solve other environmental chemical pollution problems.

\section{Acknowledgments}

This work was supported by the National Natural Science Foundation of China (no. 20877040), by a grant from the 
Technological Supporting Foundation of Jiangsu Province (no. BE2009144), by a grant from China-Israel Joint Research Program in Water Technology and Renewable Energy (no. 5), by a grant from New Technology and New Methodology of Pollution Prevention Program from Enviromental Protection Department of Jiangsu Province of China during 2010 and 2012 (no. 201001), by a grant from The Fourth Technological Development Scheming (Industry) Program of Suzhou City of China from 2010 (SYG201006), and by a grant from the Fundamental Research Funds for the Central Universities.

\section{References}

[1] M. Yazdanbakhsh, I. Khosravi, E. K. Goharshadi, and A. Youssefi, "Fabrication of nanospinel $\mathrm{ZnCr}_{2} \mathrm{O}_{4}$ using sol-gel method and its application on removal of azo dye from aqueous solution," Journal of Hazardous Materials, vol. 184, no. 1-3, pp. 684-689, 2010.

[2] N. F. Cardoso, E. C. Lima, I. S. Pinto et al., "Application of cupuassu shell as biosorbent for the removal of textile dyes from aqueous solution," Journal of Environmental Management, 2010.

[3] I. Safarik, K. Horska, and M. Safarikova, "Magnetically modified spent grain for dye removal," Journal of Cereal Science, 2010.

[4] N. Nasuha and B. H. Hameed, "Adsorption of methylene blue from aqueous solution onto $\mathrm{NaOH}$-modified rejected tea," Chemical Engineering Journal, vol. 166, no. 2, pp. 783-786, 2011.

[5] I. Safarik, L. F. T. Rego, M. Borovska, E. MosiniewiczSzablewska, F. Weyda, and M. Safarikova, "New magnetically responsive yeast-based biosorbent for the efficient removal of water-soluble dyes," Enzyme and Microbial Technology, vol. 40, no. 6, pp. 1551-1556, 2007.

[6] U. G. Akpan and B. H. Hameed, "Parameters affecting the photocatalytic degradation of dyes using $\mathrm{TiO}_{2}$-based photocatalysts: a review," Journal of Hazardous Materials, vol. 170, no. 2-3, pp. 520-529, 2009.

[7] M. A. Valenzuela, P. Bosch, J. Jiménez-Becerrill, O. Quiroz, and A. I. Páez, "Preparation, characterization and photocatalytic activity of $\mathrm{ZnO}, \mathrm{Fe}_{2} \mathrm{O}_{3}$ and $\mathrm{ZnFe}_{2} \mathrm{O}_{4}$," Journal of Photochemistry and Photobiology A, vol. 148, no. 1-3, pp. 177182, 2002.

[8] H. Yu, H. Irie, Y. Shimodaira et al., "An efficient visiblelight-sensitive $\mathrm{Fe}(\mathrm{III})$-grafted $\mathrm{TiO}_{2}$ photocatalyst," Journal of Physical Chemistry C, vol. 114, no. 39, pp. 16481-16487, 2010.

[9] S. Kitano, K. Hashimoto, and H. Kominami, "Photocatalytic degradation of 2-propanol under irradiation of visible light by nanocrystalline titanium(IV) oxide modified with rhodium ion using adsorption method," Chemistry Letters, vol. 39, no. 6, pp. 627-629, 2010.

[10] G. Fan, Z. Gu, L. Yang, and F. Li, "Nanocrystalline zinc ferrite photocatalysts formed using the colloid mill and hydrothermal technique," Chemical Engineering Journal, vol. 155, no. 1-2, pp. 534-541, 2009.

[11] S.-W. Cao, Y.-J. Zhu, G.-F. Cheng, and Y.-H. Huang, " $\mathrm{ZnFe}_{2} \mathrm{O}_{4}$ nanoparticles: microwave-hydrothermal ionic liquid synthesis and photocatalytic property over phenol," Journal of Hazardous Materials, vol. 171, no. 1-3, pp. 431-435, 2009.
[12] S. Shanmugam, A. Gabashvili, D. S. Jacob, J. C. Yu, and A. Gedanken, "Synthesis and characterization of $\mathrm{TiO}_{2} @ \mathrm{C}$ coreshell composite nanoparticles and evaluation of their photocatalytic activities," Chemistry of Materials, vol. 18, no. 9, pp. 2275-2282, 2006.

[13] H. Irie, T. Shibanuma, K. Kamiya, S. Miura, T. Yokoyama, and K. Hashimoto, "Characterization of $\mathrm{Cr}(\mathrm{III})$-grafted $\mathrm{TiO}_{2}$ for photocatalytic reaction under visible light," Applied Catalysis $B$, vol. 96, no. 1-2, pp. 142-147, 2010.

[14] K. Fuku, K. Hashimoto, and H. Kominami, "Photocatalytic reductive dechlorination of chlorobenzene to benzene in 2-propanol suspension of metal-loaded titanium(iv) oxide nanocrystals in the presence of dissolved sodium hydroxide," Chemical Communications, vol. 46, no. 28, pp. 5118-5120, 2010.

[15] R. K. Selvan, A. Gedanken, P. Anilkumar, G. Manikandan, and C. Karunakaran, "Synthesis and characterization of rare earth orthovanadate $\left(\mathrm{RVO}_{4} ; \mathrm{R}=\mathrm{La}, \mathrm{Ce}, \mathrm{Nd}, \mathrm{Sm}, \mathrm{Eu} \& \mathrm{Gd}\right)$ nanorods/nanocrystals/nanospindles by a facile sonochemical method and their catalytic properties," Journal of Cluster Science, vol. 20, no. 2, pp. 291-305, 2009.

[16] N. Shaham Waldmann and Y. Paz, "Photocatalytic reduction of $\mathrm{cr}(\mathrm{VI})$ by titanium dioxide coupled to functionalized cnts: an example of counterproductive charge separation," Journal of Physical Chemistry C, vol. 114, no. 44, pp. 18946-18952, 2010.

[17] M. Imanishi, K. Hashimoto, and H. Kominami, "Homogeneous photocatalytic mineralization of acetic acid in an aqueous solution of iron ion," Applied Catalysis B, vol. 97, no. 1-2, pp. 213-219, 2010.

[18] W. Zhang, J. Zhang, Z. Chen, and T. Wang, "Photocatalytic degradation of methylene blue by $\mathrm{ZnGa}_{2} \mathrm{O}_{4}$ thin films," Catalysis Communications, vol. 10, no. 13, pp. 1781-1785, 2009.

[19] W. Zhang, J. Zhang, X. Lan, Z. Chen, and T. Wang, "Photocatalytic performance of $\mathrm{ZnGa}_{2} \mathrm{O}_{4}$ for degradation of methylene blue and its improvement by doping with Cd," Catalysis Communications, vol. 11, no. 14, pp. 1104-1108, 2010.

[20] J. Tang, Z. Zou, and J. Ye, "Effects of substituting $\mathrm{Sr}^{2+}$ and $\mathrm{Ba}^{2+}$ for $\mathrm{Ca}^{2+}$ on the structural properties and photocatalytic behaviors of $\mathrm{CaIn}_{2} \mathrm{O}_{4}$," Chemistry of Materials, vol. 16, no. 9, pp. 1644-1649, 2004.

[21] J. Tang, Z. Zou, J. Yin, and J. Ye, "Photocatalytic degradation of methylene blue on $\mathrm{CaIn}_{2} \mathrm{O}_{4}$ under visible light irradiation," Chemical Physics Letters, vol. 382, no. 1-2, pp. 175-179, 2003.

[22] R. J. Tayade, T. S. Natarajan, and H. C. Bajaj, "Photocatalytic degradation of methylene blue dye using ultraviolet light emitting diodes," Industrial and Engineering Chemistry Research, vol. 48, no. 23, pp. 10262-10267, 2009.

[23] C.-H. Chen, Y.-H. Liang, and W.-D. Zhang, " $\mathrm{ZnFe}_{2} \mathrm{O}_{4}$ / MWCNTs composite with enhanced photocatalytic activity under visible-light irradiation," Journal of Alloys and Compounds, vol. 501, no. 1, pp. 168-172, 2010.

[24] B. Cui, H. Lin, Y.-Z. Liu et al., "Photophysical and photocatalytic properties of core-ring structured $\mathrm{NiCo}_{2} \mathrm{O}_{4}$ nanoplatelets," Journal of Physical Chemistry C, vol. 113, no. 32, pp. 14083-14087, 2009.

[25] H. Zhang, K. Tan, H. Zheng, Y. Gu, and W. F. Zhang, "Preparation, characterization and photocatalytic activity of $\mathrm{TiO}_{2}$ codoped with yttrium and nitrogen," Materials Chemistry and Physics, vol. 125, no. 1-2, pp. 156-160, 2011.

[26] J. Luan, K. Ma, L. Zhang, M. Li, Y. Li, and B. Pan, "Research on different preparation methods of new photocatalysts," Current Organic Chemistry, vol. 14, no. 7, pp. 683-698, 2010. 
[27] M. Kitano, M. Takeuchi, M. Matsuoka, J. M. Thomas, and M. Anpo, "Preparation of visible light-responsive $\mathrm{TiO}_{2}$ thin film photocatalysts by an RF magnetron sputtering deposition method and their photocatalytic reactivity," Chemistry Letters, vol. 34, no. 4, pp. 616-617, 2005.

[28] M. Anpo, H. Yamashita, K. Ikeue et al., "Photocatalytic reduction of $\mathrm{CO}_{2}$ with $\mathrm{H}_{2} \mathrm{O}$ on Ti-MCM-41 and Ti-MCM-48 mesoporous zeolite catalysts," Catalysis Today, vol. 44, no. 1-4, pp. 327-332, 1998.

[29] M. Anpo and M. Takeuchi, "The design and development of highly reactive titanium oxide photocatalysts operating under visible light irradiation," Journal of Catalysis, vol. 216, no. 1-2, pp. 505-516, 2003.

[30] M. Hamadanian, A. Reisi-Vanani, and A. Majedi, "Preparation and characterization of S-doped $\mathrm{TiO}_{2}$ nanoparticles, effect of calcination temperature and evaluation of photocatalytic activity," Materials Chemistry and Physics, vol. 116, no. 2-3, pp. 376-382, 2009.

[31] J. Luan, W. Zhao, J. Feng et al., "Structural, photophysical and photocatalytic properties of novel $\mathrm{Bi}_{2} \mathrm{AlVO}_{7}$," Journal of Hazardous Materials, vol. 164, no. 2-3, pp. 781-789, 2009.

[32] J. Marugán, D. Hufschmidt, G. Sagawe, V. Selzer, and D. Bahnemann, "Optical density and photonic efficiency of silicasupported $\mathrm{TiO}_{2}$ photocatalysts," Water Research, vol. 40, no. 4, pp. 833-839, 2006.

[33] S. Sakthivel, M. V. Shankar, M. Palanichamy, B. Arabindoo, D. W. Bahnemann, and V. Murugesan, "Enhancement of photocatalytic activity by metal deposition: characterisation and photonic efficiency of $\mathrm{Pt}, \mathrm{Au}$ and $\mathrm{Pd}$ deposited on $\mathrm{TiO}_{2}$ catalyst," Water Research, vol. 38, no. 13, pp. 3001-3008, 2004.

[34] F. Izumi, "A software package for the rietveld analysis of X-ray and neutron diffraction patterns," Journal of Crystallographic Association, Japan., vol. 27, pp. 23-26, 1985.

[35] Z. Zou, J. Ye, and H. Arakawa, "Preparation, structural and photophysical properties of $\mathrm{Bi}_{2} \mathrm{InNbO}_{7}$ compound," Journal of Materials Science Letters, vol. 19, no. 21, pp. 1909-1911, 2000.

[36] G. Liu, T. Wu, J. Zhao, H. Hidaka, and N. Serpone, "Photoassisted degradation of dye pollutants. 8. Irreversible degradation of alizarin red under visible light radiation in airequilibrated aqueous $\mathrm{TiO}_{2}$ dispersions," Environmental Science and Technology, vol. 33, no. 12, pp. 2081-2087, 1999.

[37] H. Lachheb, E. Puzenat, A. Houas et al., "Photocatalytic degradation of various types of dyes (Alizarin S, Crocein Orange G, Methyl Red, Congo Red, Methylene Blue) in water by UV-irradiated titania," Applied Catalysis B, vol. 39, no. 1, pp. 75-90, 2002.

[38] C. Nasr, K. Vinodgopal, L. Fisher, S. Hotchandani, A. K. Chattopadhyay, and P. V. Kamat, "Environmental photochemistry on semiconductor surfaces. Visible light induced degradation of a textile diazo dye, naphthol blue black, on $\mathrm{TiO}_{2}$ nanoparticles," Journal of Physical Chemistry, vol. 100, no. 20, pp. 84368442, 1996.

[39] M. Wiegel, W. Middel, and G. Blasse, "Influence of NS2 ions on the luminescence of niobates and tantalates," Journal of Materials Chemistry, vol. 5, no. 7, pp. 981-983, 1995. 


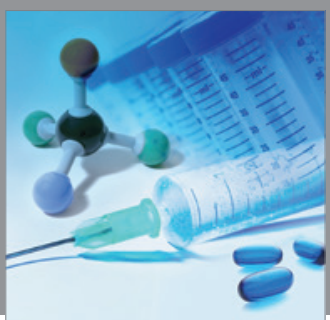

International Journal of

Medicinal Chemistry

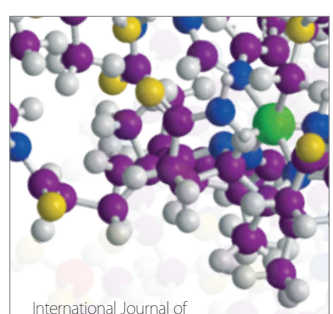

Carbohydrate Chemistry

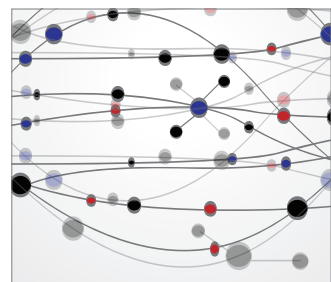

The Scientific World Journal
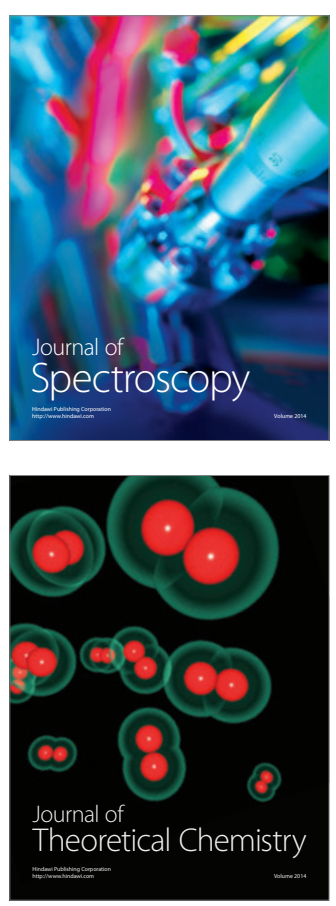
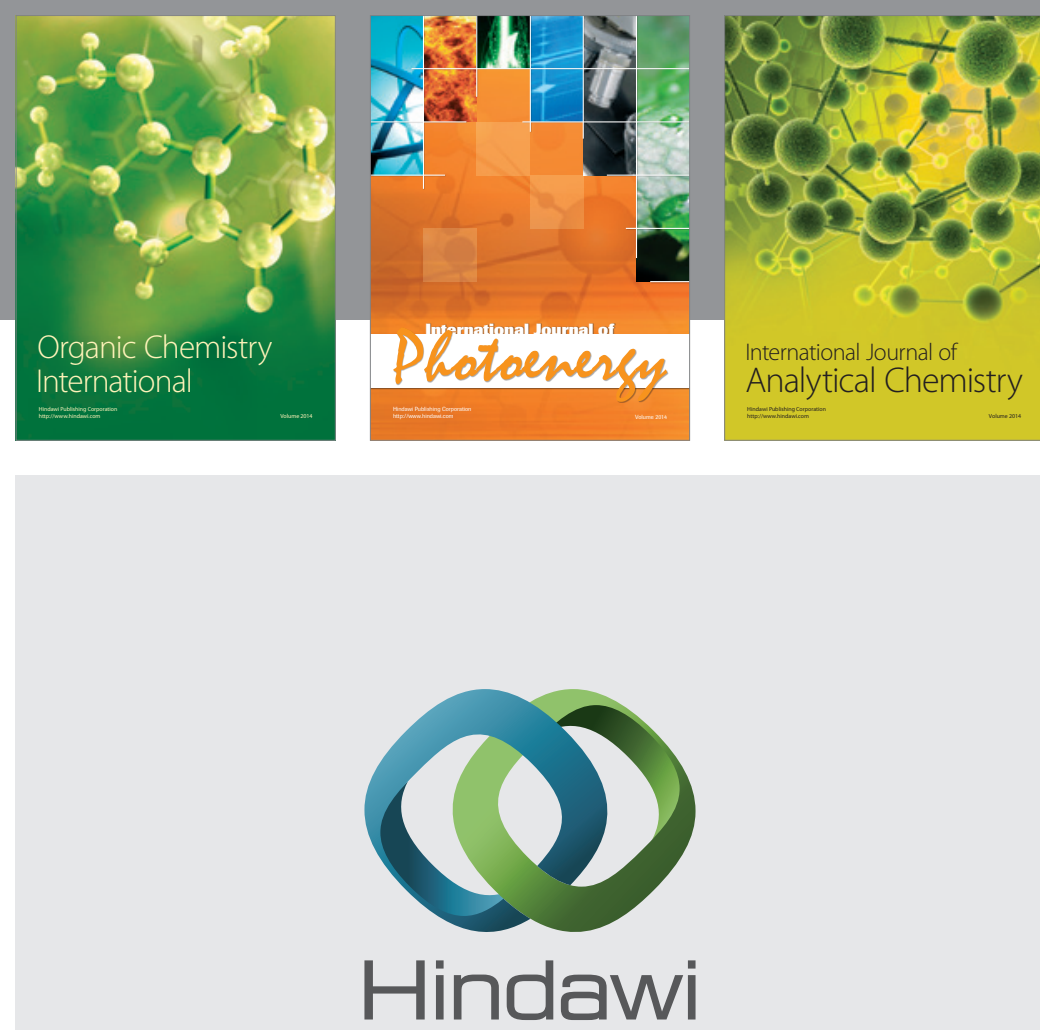

Submit your manuscripts at

http://www.hindawi.com
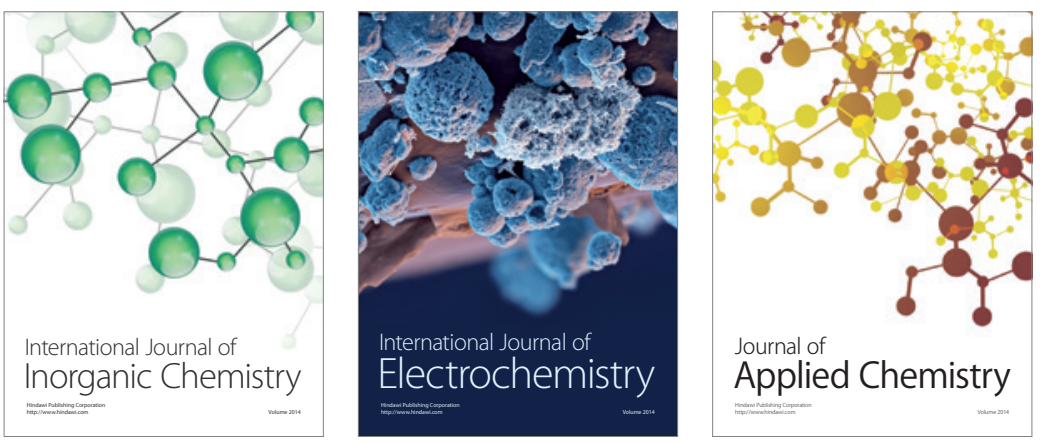

Journal of

Applied Chemistry
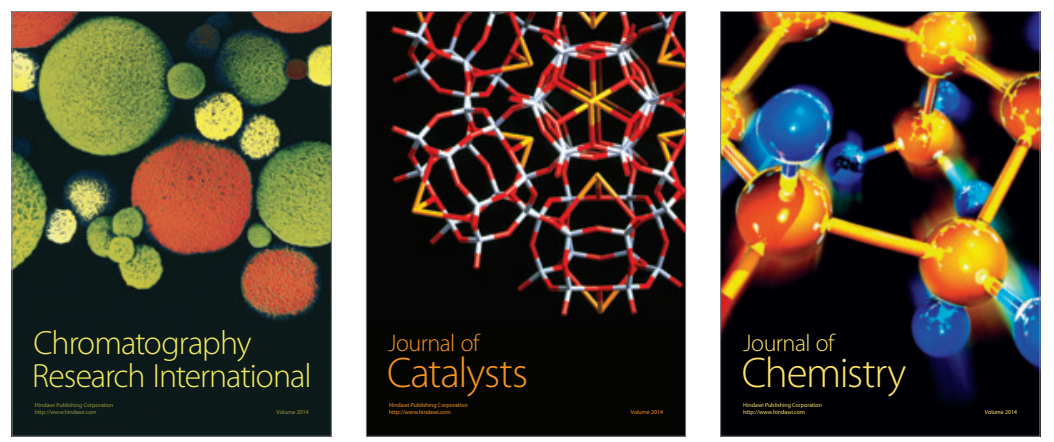
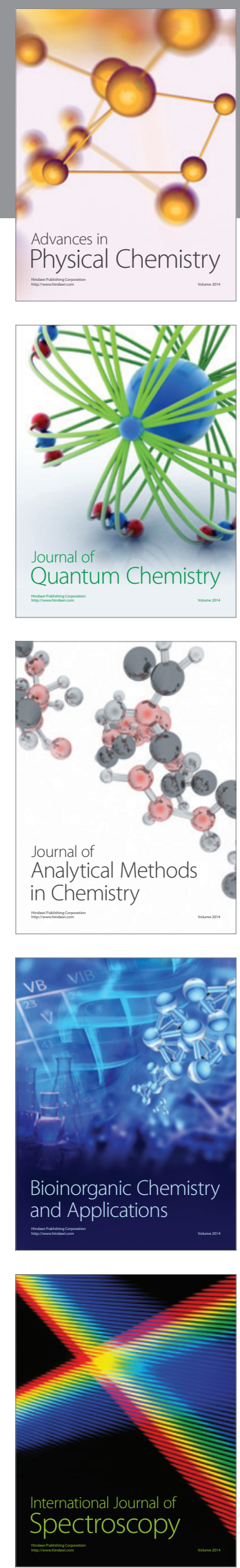